CHILDREN'S AND PARENTS' THOUGHTS AND FEELINGS REGARDING NATURE IN TWO TYPES OF LOCATIONS: COMPARISONS AND IMPLICATIONS

$$
\text { by }
$$

Magdalena (Maggie) Rudkowski, B.A., Ryerson University, 2007

\author{
A Major Research Paper \\ Presented to Ryerson University \\ in partial fulfillment of the requirements for the degree of \\ Masters of Arts \\ in the Program of \\ Early Childhood Studies
}

Toronto, Ontario, Canada, 2008

(C) Magdalena Rudkowski 2008 


\title{
CHILDREN'S AND PARENTS' THOUGHTS AND FEELINGS REGARDING NATURE IN TWO TYPES OF LOCATIONS: COMPARISONS AND IMPLICATIONS
}

(C) Magdalena (Maggie) Rudkowski, 2008

\author{
Master of Arts \\ Early Childhood Studies \\ Ryerson University
}

\begin{abstract}
This study examines the nature thoughts and feelings of $6-12$ year-old children and their parents living in mountainous and city regions. It asks whether location and parental influences play roles in children's responses. Hypotheses assumed that participants in mountainous locations would be more connected with nature and that children's and parents' nature thoughts would correlate. Using mix-methods, surveys were distributed to 192 participants. Results illustrated that children in mountainous regions displayed more emotion words while children in the city displayed more descriptive words. No significant differences were found between parents. Compared to the urban sample, participants in mountainous regions felt that their environment was more a part of nature. Lastly, descriptive and total number of words correlated for parents and children. Recommendations include suggestions for curriculum design and childhood experiences. Parents, educators, and policy-makers should provide more unstructured outdoor play opportunities.
\end{abstract}

Key Words: Nature, Nature Attitudes, Urban Environments, Mountainous Regions, Parental Influences, Ecological Literacy, Environmental Education 


\section{Acknowledgements}

I sincerely would like to thank all the wonderful people that have been supporting me throughout the challenging, yet rewarding journey. First and foremost, I would like to thank my research supervisor, Dr. Robert Rinkoff, for his guidance, support and expertise, as well as teaching me the valuable process of a mix-method research study. With that, I would also like to thank Dr. Patricia Corson for her encouragement, wise and thoughtful feedback. I am very much grateful for Dr. Rachel Berman, Dr.Celina Kwan-Green and Dr.Judith Bernhard for their unlimited support and guidance right from the beginning.

I am thankful for my patient, understanding and optimistic parents, Bonnie and Matthew, who taught me the wonders and joys of nature early on in my childhood years. I am grateful for my brother, Paul, who was always willing to give generous feedback, and to my grandparents, who were always there for me. I can never give enough thanks to my close friends, who gave me boundless emotional support throughout the hardships. Thank you to my wonderful MECS friends, who became my valuable support group and could always depend on. In the wise words of Winston Churchill, "Never, never, never, never give up." 


\section{Table of Contents}

Author's Declaration

Abstract

Acknowledgements

vii

List of Appendices

$\mathrm{xi}$

Literature Review

Direct Nature Experiences

2

Modern Society

Parents' Influences on Children's Nature Attitudes

4

Environmental Education (EE) Curriculum

Geographical Location

Research Purpose

Research Questions

Hypothesis

Definition of Terms

Nature

12

Urban/City Environments

Mountainous Environments

13

Thoughts and Feelings Regarding Nature

Methodology

Mix-Method Design

Setting/Location

Participants

Sampling Method

Variables

Research Tools

Data Collection Procedure

Data Analysis Procedure

Qualitative Analysis 
Quantitative Analysis

Merging the Open and Closed-Ended Data 20

$\begin{array}{ll}\text { Validity and Reliability } & 20\end{array}$

$\begin{array}{lr}\text { Ethics and Human Relations } & 20\end{array}$

$\begin{array}{ll}\text { Findings } & 21\end{array}$

What is the impact of location on children's thoughts and feelings towards nature? $\quad 21$

What is the impact of location on parents' thoughts and feelings towards nature? 25

What are the differences between children's and parents' thoughts and feelings 28 towards nature?

Discussion

Limitations of the Study

$\begin{array}{ll}\text { Recommendations for Future Research } & 38\end{array}$

$\begin{array}{lr}\text { Conclusion } & 40\end{array}$

$\begin{array}{ll}\text { Appendices } & 43\end{array}$

$\begin{array}{ll}\text { Resources } & 65\end{array}$

$\begin{array}{ll}\text { References } & 67\end{array}$ 


\section{List of Appendices}

Appendix A. Copy of Introduction Flyer

Appendix B. Copy of Survey Questions for Children 44

Appendix C. Copy of Survey Question for Parents 46

$\begin{array}{lll}\text { Appendix D. Triangulation Mix-Method Design Chart } & 47\end{array}$

$\begin{array}{lll}\text { Appendix E. Definitions of Word Categories } & 48\end{array}$

Appendix F. Breakdown of Participants 49

$\begin{array}{lll}\text { Appendix G. Assent Agreement for Children } & 50\end{array}$

Appendix H. Assent Agreement for Parents 52

$\begin{array}{lll}\text { Appendix I. } & \text { T-Test Scores for Children } & 56\end{array}$

$\begin{array}{lll}\text { Appendix J. } & \text { T-Test Scores for Parents } & 58\end{array}$

$\begin{array}{lll}\text { Appendix K. Sample of Word Document Chart } & 60\end{array}$

$\begin{array}{lll}\text { Appendix L. Consent Agreement for Principals } & 61\end{array}$ 


\title{
Children's and Parents' Thoughts and Feelings Regarding Nature in Two Types of Locations: Comparisons and Implications
}

\begin{abstract}
"Without continuous hands-on experience, it is impossible for children to acquire a deep intuitive understanding of the natural world that is the foundation of sustainable development. ....A critical aspect of the present-day crisis in education is that children are becoming separated from daily experience of the natural world, especially in larger cities." (Moore \& Wong, 1997)
\end{abstract}

Past literature has shown many benefits of nature to a child's physical and psychological wellbeing (Haluza-Delay, 2001; Hamilton, Klebanoff \& Sharp, 1991; Wells \& Evans, 2003; Zeece \& Wells, 2007). When connected to nature, a child will develop a deeper selfunderstanding. This provokes self-reflection and appreciation, and increases curiosity and problem-solving skills, which lead to overall academic success (Haluza-Delay, 2001; Zeece \& Wells, 2007). Connections with nature also decrease behavioural aggression and stress levels, encourage appreciation for self as well as others, and increase understanding and appreciating diversity in life. Lastly, a child will adapt their environmental experiences into new learning experiences, benefitting their academic performance (Hamilton, Klebanoff \& Sharp, 1991; Zeece \& Wells, 2007).

Equally important, forming deep connections to nature in early life is important for maintaining pro-environmental attitudes in the future (Korhonen \& Lappalainen, 2004; Van Petegem \& Blieck, 2006). It is known that in adulthood, an individual's behaviour towards the environment is strongly influenced by consistent early experiences with nature. In order to maintain a healthy environment for the future as well as provide children with optimum opportunities for success, it is vital for researchers to explore young children's connections with nature. Therefore, it is important to study whether geographical location as well as parental guidance influences a child's thoughts and feelings in regards to nature. The following literature 
review will discuss significant factors that influence a child's perceptions, attitudes and knowledge of the environment, including: direct nature experiences, modern society, parents' influences, environmental education (EE) curriculum, and the impact of geographic locations.

\section{Direct Nature Experiences}

The literature reviewed for this study has shown that direct experience with nature plays the most vital role in influencing environmental attitudes, especially in the early years (Taylor, Kuo \& Sullivan, 2002; Wells \& Lekies, 2006; Zaradic \& Pergams, 2007). Yet, research such as this is still fairly new to early childhood studies.

By surveying 2,000 adults aged 18 to 19 living in urban areas throughout United States, Wells and Lekies (2006) found that adults who had direct nature experiences prior to age 11 had higher levels of pro-environmental attitudes. Through 108 closed-ended questionnaires concerning childhood participation and experiences with nature, the authors have found that adults who consistently partook in nature -related activities in childhood, including walking, playing outdoors, hiking, and camping had significantly higher levels of caring attitudes towards the environment in adulthood (Wells \& Lekies, 2006). Model testing and cross-validation procedures using structural equations were used to test validity and reliability (Wells \& Lekies, 2006). These findings support the notion that it is crucial for children to be exposed to nature at an early stage to establish meaningful connections with the natural world, especially proving that these early experiences have an incredible impact on life-long attitudes and perspectives on environmentalism.

Similarly, Taylor, Kuo and Sullivan (2002) illustrated that having consistent contact with nature improves levels of self-discipline in girls aged 7 to 12 years, including concentration levels, initial impulses and delaying gratification. By randomly assigning 169 inner-city children 
from twelve architecturally identical high-rise buildings, participants were assessed on four different items: near-home nature assessment levels that asked parents to rate on a 5-point rating scale the amount of nature and man-made materials seen through their windows; four standardized concentration assessment tasks, three standardized initial impulses assessment tests as well as a version of standardized gratification assessment task to measure gratification levels (Taylor et al, 2002). Once results were combined and correlated, Taylor et al (2002) found that girls living in a nature-enriched neigbourhoods perform significantly better at all areas of selfdiscipline. With a large sample size and using standardized assessments to establish comprehensive results, this study contributes to the understanding of nature and its direct impacts on children's cognitive and behavioural development. However, while the study establishes the notion that behaviours such as self-discipline are influenced by experiences with nature in girls, it would be beneficial to extend these results to include the impacts that nature has on boys.

By establishing validity and reliability as well as using large sample sizes, these quantitative studies show that having direct contact with nature in the early years plays a significant role not only in pro-environmental attitudes, but also increases cognitive abilities (Taylor el al, 2002; Wells \& Lekies, 2006). Studies such as these illustrate the importance of nature being a part of a child's everyday life. However, they do not go beyond and illustrate the types of relationships children have with nature in various environments. Research in this field is found mostly in the United States (Taylor el al, 2002; Wells \& Lekies, 2006) and focuses solely on direct-nature experiences. Additionally, comparisons of high-nature and low-nature experiences have been overlooked, and for this reason further investigation is needed. 


\section{Modern Society}

Children's play-environments have drastically changed in modern societies (Bonnett \& Williams, 1998; Pergams \& Zaradic, 2006; Zaradic \& Pergams, 2007). Television, video games and other media influences are beginning to play the dominant role in a child's development, further disconnecting them from the natural world (Bonnett \& Williams, 1998; Zaradic \& Pergams, 2007). Zaradic and Pergams (2007) coined the term videophilia, which is described as the increased human tendency to focus on activities involving technology. Although direct nature experiences are known as the most influential factor in shaping nature attitudes, Zaradic and Pergams (2007) discuss the increasing number of children substituting spending time outdoors for technology-focused play, such as video games, internet and television. This videophilia trend has drastic consequences, including issues of increased loneliness, attention-deficit disorders and depression (Zaradic \& Pergams, 2007). Although this research is conducted on the American population, it could be related to the increasing trends of the Canadian society.

Bonnett and Williams (1998) emphasize that children are placing an increasing value on media as the primary source of their knowledge about the world. It is also shown that media frequently forms a false perception of nature, in addition to devoting less media coverage to environmental concerns. In their pilot study of exploring $5^{\text {th }}$ and $6^{\text {th }}$ grade student's attitudes towards nature, the participants discussed how music videos, television shows, cartoons and news stories shaped their knowledge about nature. Depending on the child's upbringing, a child might heavily rely on the media to form an understanding about the wilderness. Results indicated similarities to Zaradic and Pergams (2007) study, in which children began to associate nature with boredom and danger, based on the information they had gathered from the media (Bonnett \& Williams, 1998). Based on this evidence, it is vital to explore the current perspectives, 
attitudes and experiences that children are having with nature. As highlighted in the following section, this is especially significant for children who attend education programs whose main goal is to re-connect children with nature.

\section{Parents' Influences on Children's Nature Attitudes}

Social influences are strong predictors of environmental behaviours., Previous studies have illustrated that parents have strong influences over their child's attitudes, especially in the early years (Alp, Ertepinar, Tekkaya \& Yilmaz, 2008; Devine-Wright, Devine Wright \& Fleming, 2004; Hyun, 2005). A study completed by Hyun (2005) compared the perceptions about nature of children's and adults' mental processes. By conducting field notes and insightful observations, vignettes were formed in naturalistic settings (such as parks, child care settings, and participant homes) and analyzed using axial, open, and selective coding, making the results insightful and comprehensive. Results illustrated that, although there were gender-biased interaction between parents and children, children's sense of the environment was largely shaped by their parental attitudes (Hyun, 2005). Since attitudes are a prerequisite for displaying behaviours pro-environmentally parents were seen to shape their children's attitudes by exposing them to natural environments, as well as educating them about nature's importance (Hyun, 2005).

Alp, Ertepinar, Tekkaya and Yilmaz (2008) found similar results while studying environmental behaviours of 1,140 Turkish sixth and eight grade students, seeing if parental educational levels as well as gender differences influence a child's perspective towards nature. By randomly sampling participants with the Children's Environmental Attitudes and Knowledge Scale as well as Locus of Control Scale, results showed that students whose fathers had higher education levels were more educated and aware about environmental issues (Alp et al, 2008). 
Further discussion proposed that this was due to the fathers' knowledge about environmental issues, time dedication and a child's accessibility to valuable information and time in nature (Alp et al, 2008).

Other studies, such as the Devine-Wright, Devine-Wright and Fleming (2004) study exploring a child's influences about their global warming ideologies, also revealed that parents have important roles in passing down nature-attitudes. By distributing Likert-type question surveys about global warming issues, 198 children aged 9 to 12 years of age and 57 adults from the Woodcraft Folk environmental and social-justice organization participated. As a comparison, 59 children from elementary schools were also given the surveys. Results indicated that parents in the Woodcraft Folk organization were more likely to educate their children about environmental issues, following environmental beliefs and giving empowerment to their children (Devine-Wright et al, 2004). Overall, this study supports the findings of previous research that children need strong role models for passing on positive environmental behaviours. For instance, seeing parents partake in environmentally-friendly behaviours will show them the importance of nature (Alp et al, 2008; Devine-Wright et al, 2004; Hyun, 2005).

\section{Environmental Education (EE) Curriculum}

One of the central goals of quality environmental education programs is to re-connect children with the natural world by providing children with the knowledge and the direct experiences with nature that they may not receive in their everyday world (Haluza-Delay, 2001; Johnson-Pynn \& Johnson, 2005; Korhonen \& Lappalainen, 2004). As past literature points out, such programs do have a strong impact on the way a child sees the environment (Haluza-Delay, 2001; Johnson-Pynn and Johnson, 2005). Among the wealth of research, there have been significant findings that illustrate the effects that environmental programs have on children. Most 
importantly, participation in quality environmental education programs empowers and encourages children to act upon their concerns for issues surrounding the natural environment. By providing practical knowledge and hands-on experiences, consistent programming provides students with the techniques to promote positive change in their communities (Haluza-Delay, 2001; Korhonen \& Lappalainen, 2004).

Haluza-Delay (2001) explored the effects of a twelve-day wilderness adventure program for eight youth aged 14 to 16 years old in Alberta, Canada. The participants were encouraged to actively partake in outdoor activities that were absent from their everyday lives, such as rockclimbing, canoeing, backpacking and nature walks. During this time, field notes and observations were made. There was also an attempt to build a rapport with each of the participants. Afterwards, two individual semi-structured interviews were conducted with each of the participants; the first interview was held immediately after the adventure program finished and the second phase of interviews took place six months after the trip. Through the rich combination of data collection, Haluza-Delay (2001) ensured credible and validated results. Results indicated that after the twelve-day period, the youths were noted to feel a deeper connection with the environment, causing them to act upon their attitudes (Haluza-Delay, 2001). Overall, this study has illustrated that effective environmental programs have the ability to motivate an individual to gain deeper connections with nature. However, it would be beneficial to examine programs or educational systems that operate on a long-term basis to see if they too have similar effects, in addition to examining if younger children would display the same results.

Comparable results were found by Johnson-Pynn and Johnson (2005) from their study of documenting the experiences of students participating in two-school based environmental education programs in East Africa: the Jane Goodall Institute's Roots \& Shoots (R\&S) in 
Tanzania and Wildlife Clubs of Uganda (WCU). Multiple methods of data collection were used, adopting an exploratory design. Overall, the data collection methodology included focus groups with primary and secondary school students, five interviews with teachers and with six program coordinators, self report Likert-scale instruments for 105 secondary school students about participating in these two programs, observations as well as participatory observations throughout the program duration. By using multiple data collection methods and triangulation design for analysis, it ensured comprehensive and validated results. Results illustrated that students participating were more positive and knowledgeable about the environment, as well as becoming determined to enhance the nature surroundings within their communities.

These studies suggest that environmental education (EE) programs have a significant impact on a child's sense of connection and attitudes towards nature (Haluza-Delay, 2001; Johnson-Pynn \& Johnson, 2005). However, these studies were based on short-term programs that were held outside of a child's educational school system. Further studies would be beneficial to examine the type of role that full-time school curriculum which has a nature-based component in their everyday practices has on the child-nature relationship. As discussed in the following section, it would also be valuable to explore the possibility that the child's everyday environment has on his or hers attitudes towards the environment.

\section{Geographical Location}

There is an increasing amount of evidence that supports the belief that location has a great impact on the formation of attitudes towards nature (Barraza,1999; Korhonen \& Lappalainen, 2004; Van Petegem \& Blieck, 2006). Van Petegem and Blieck (2006) conducted a study to compare the environmental worldviews of children living in Belgium and Zimbabwe. Using a significant sample of 613 children in Belgium and 524 children in Zimbabwe who were 
aged 13 to 15 years, results indicated attitude differences between the two regions. Although both groups of children were seen as environmentally conscious, their environmental viewpoints of human-nature element differed. Within the Zimbabwe sample, the majority of children believed that there was a human dominance over nature and that the environment could survive the needs of the modern industry. On the other hand, Belgium children expressed environmentally protective and fearful attitudes of the possible damage that could be caused by progressive technology (Van Petegem \& Blieck, 2006). Van Petegem and Blieck (2006) hypothesize that these attitudes could be reflective of the communities in which the children reside. As opposed to the Zimbabwe sample, children in Belgium live in fast-paced industrialized communities in which they are surrounded by modern-aged advances, in addition to being more prone to the media's message of environmental issues, resulting in more fearful and cautious environmental attitudes.

Korhonen and Lappalainen (2004) also presented similar results while comparing nature attitudes of 8 to 21 year old students in forested and deforested communities within Ranomafana, Madagascar. Using two types of semi-structured questionnaires in 18 schools, results illustrated that children living in deforested regions presented a stronger demand for action and concern for the environment. Korhonen and Lappalainen (2004) suggested two reasons for this differentiation. Firstly, children living in forested areas were not directly exposed to the extent of environmental damage taking place, as the children in the industrialized areas were. Secondly, children in the deforested region were partaking in environmental education (EE) programs, which increased their environmental awareness and concern. In addition to participating in the environmental programs, results suggest that a child's community and natural surroundings are significant to their understanding of nature (Korhonen \& Lappalainen, 2004). 
A further study by Barraza (1999) comparing school children-nature relationships between England and Mexico had contrasting results. Participants aged 7 to 9 years of age were asked to draw a picture of the environment in order to examine if culture and school had a role in their environmental perspectives. The participant pictures were then analyzed and compared among a total of 8 schools; 3 schools in England and 5 in Mexico. Results showed that children from these two countries had more similarities than differences. Both groups of children illustrated high environmental concern, as well as pessimistic viewpoints on the future state of earth. One difference between the groups was that the Mexican children frequently drew the world with the South American continent emphasized, while children from England emphasized the European continent (Barraza, 1999). Barraza (1999) proposed these results happened for three reasons: participants had similar socio-economic statuses in both countries, children in both countries were from urban communities, and lastly, all children had similar access to mass media and internet resources.

These studies examined the influence that geographical location has on a child's relationship with nature. Comparisons between regions of Belgium and Zimbabwe, forested and deforested regions in Madagascar, as well as England and Mexico have all been discussed (Barraza, 1999; Korhonen \& Lappalainen, 2004; Van Petegem \& Blieck, 2006). With validated methodologies and comprehensive results, all of the studies indicate that the surrounding landscape does play a role in a child's environmental attitudes. However, there are still missing gaps which are needed to be filled. Past literature has examined the attitudes towards environmental issues and standpoints, but further research needs to be given on the overall childnature relationship that is formed in early childhood. Furthermore, it is crucial to look into communities that are situated in urbanized and rural areas in an industrialized, technological- 
advanced country, and see whether the child's natural surroundings play a part in their relationship with nature.

The literature reviewed in this paper has identified various predominant variables that potentially impact a child's relationship with nature. Direct experiences, media and technology, education programs, as well as geographical location have been identified as important factors in shaping a child's attitudes towards the environment.

\section{Research Purpose}

The literature has not addressed the questions which are embedded in this study's main purpose, which is to investigate how children's thoughts and feelings towards nature vary according to where they live and whether the children's thoughts and feelings about nature correspond to parents' thoughts and feelings about nature to see whether parents play a major influence on the children's attitudes.

\section{Research Questions}

In summary, work has been conducted in the field of the environment as it relates to direct experiences with nature, influences of modern technology and media, environmental education programs and influences of geographical locations. Nevertheless, the questions related to this research have not been addressed, specifically:

1. What is the impact of location on children's thoughts and feelings towards nature?

2. What is the impact of location on parents' thoughts and feelings towards nature?

3. What are the differences between children's and parents' thoughts and feelings towards nature? 


\section{Hypotheses}

Based on the evidence that the past literature presented as well as in the study completed by Rinkoff and Gaston (2008), it is hypothesized that:

1. Children's and parents' thoughts and feelings towards nature will vary between the urban and mountainous locations. Specifically, participants living in the mountainous locations will be more connected with nature, relating themselves with nature more so than the participants living in urban locations.

2. Children's and parents' thoughts and feelings towards nature will correlate with each other. Therefore, the parents will display similar responses to their children's on the survey questions.

These two locations were selected for two main reasons. First, urban and mountainous environments have evident dissimilarities between each other, therefore, making them ideal locations for comparisons to be made. Secondly, the present study was based on Rinkoff and Gaston's (2008) study and previously collected data was used.

\section{Definition of Terms}

\section{Nature}

According to the Cambridge Dictionary (2008), nature is defined as, "all the animals, plants, rocks, etc. in the world and all the features, forces and processes that happen or exist independently of people, such as the weather, the sea, mountains, reproduction and growth."

\section{Urban/City Environments}

Urban Environments are defined as locations that are highly- industrialized, and are populated with a greater number of people. In reference to this particular research study, urban 
environments are located as settings in which families do not have access to mountainous regions or wilderness (such as forests).

\section{Mountainous Environments}

As opposed to urban settings, mountainous environments are defined as locations which are situated near wilderness areas, including forests, parks and mountains. For this specific study, families living in rural areas are situated near two mountainous regions.

\section{Thoughts and Feelings Regarding Nature}

Thoughts and feelings about nature encompass the attitudes and perspectives that individuals hold towards natural environments.

\section{Methodology}

\section{Mix-Method Design}

The data collection tools as well as the data collected were obtained from a section of Rinkoff's and Gaston's (2008) study on children's relationships with the mountain environment, entitled, "The child's proximity to mountains as a predictor of environmental intimacy: Implications for stewardship. " For a comprehensive mix-method research collection, the triangulation design was used. Using open- and closed-ended surveys, the data was simultaneously gathered by both qualitative and quantitative measurements, which are of equal strengths (Creswell, 2005). As shown in Appendix D, qualitative and quantitative data were analyzed individually and then merged for direct comparisons. This ensured in-depth and comprehensive results, where one form of data-collection fills in the weaknesses that the other data-collection tool presents and allowing the researcher to use the strengths of each datacollection tools (Creswell, 2005). 


\section{Setting/Location}

In order to suit the purpose of this research study, students from grades one, three and five along with their parents from two towns in mountainous regions and one central city environment were recruited to participate in this study. The schools in the mountainous region were chosen on the basis of their proximity to mountain parks. In contrast, the central city school was chosen because it was in a large metropolitan area distant from any mountain parks. Three schools in all were used.

\section{Participants}

To attain the goal of this research, the participating sample was formed by children aged 6 to 12 years of age, along with their parents from two towns and one metropolitan city. Depending on the school's enrollment and participation willingness, the resulting numbers of participants varied from region to region, as well as between parents and children. In total, 103 children and 89 parents participated: 63 children and 53 parents were from mountainous areas and 40 children and 36 parents were from the urban region. This resulted in a total of 192 participants. Generating this sample fulfilled the requirements of the study's purpose, as well it ensured that appropriate comparisons were made (Creswell, 2005).

\section{Sampling Method}

To diminish sampling error and to gain a valid and insightful sample, the purposeful sampling technique was used throughout the mix-method research study (Del Balso \& Lewis, 2001). The aim of purposeful sampling design is to intentionally select participants and locations in order to attain specific information, which is the central goal of this research design (Creswell, 2005). Since the present study aims to examine the perspectives of children and parents attending 
various elementary schools in two types of contrasting locations, this sampling procedure was seen as ideal.

\section{Variables}

The first independent variable is defined as the two types of physical locations that the participants are living in. Additionally, the second independent variable is whether the participant was a child or a parent. Furthermore, the dependent variable is identified as the child's and parent's thoughts and feelings regarding nature in their everyday lives. For the main intent of this study, the dependent variable was measured by individual surveys as described below. These surveys are crucial for gaining an insight into how each participant thinks about nature. However, the first independent variable was chosen by the project's supervisor when he selected the various locations of these schools.

\section{Research Tools}

In order to gather comprehensive data, semi-structured surveys were used for children as well as parents to complete. Authentic to the mix-method design, the survey had a combination of closed and open-ended questions that included multiple-choice and open-ended word listing questions (Cohen, Manion \& Morrison, 2003). The surveys consisted of three questions on the child surveys and three questions on the parental surveys measuring the thoughts and feelings that participants have regarding nature. These questions examined words that come to mind when thinking about nature, how much a part of nature the participant feels, and how much a part of nature do they feel their home is. For complete questions please refer to Appendix $B$ and C.

The survey questions were taken from a section of Rinkoff and Gaston (2008) research study on children's relationship with the mountain environment, entitled, "The child's proximity 
to mountains as a predictor of environmental intimacy: Implications for stewardship." Overall, this methodology ensured that the research tools provided a rich-combination of data that directly corresponded to the research purpose of examining children's and parents' thoughts and feelings about nature (Creswell, 2005).

\section{Data Collection Procedures}

The survey was distributed in various schools located in three areas: two towns in mountainous regions and one urban city. The schools were chosen based on their willingness to participate. Prior to beginning, principals were contacted in order to provide an explanation of the research project, and to provide recruitment information, principals were also asked to sign a consent form (for reference, refer to appendix $B$ and appendix $C$ ). Once approved, the investigator sought the consent of classroom teachers, parents and lastly, the students. A package consisting of the project's introduction, recruitment information, assent forms and surveys were distributed to the children's home. The participants were then asked to voluntarily complete the surveys at home and return them to the classroom teachers once completed. The classroom teachers collected the surveys and returned them to the primary investigator. The process lasted approximately two weeks in total.

\section{Data Analysis Procedures}

Using the triangulation design analysis, the qualitative and quantitative data were separately analyzed and compared to each other at the end (Creswell, 2005). This fitted this particular study, as it gave the opportunity to establish both validity and reliability as well as achieve credible results. Further, the analysis of the qualitative and quantitative data is separate to determine if these designs support each other and formulate final conclusions (Creswell, 2005). 
Prior to beginning, coding was developed for the participants and the two types of areas that were used in this study. The areas were given numbers of 1 and 2 to distinguish the mountainous and urban areas. From there, the children and parent participants were separated into two different sections, and were then numbered from 1 to the total number of participants for both parents and children in two separate SPSS spreadsheets. This allowed for confidentiality to be maintained, as well as avoiding skewing the data with the researcher's biases.

\section{Qualitative Analysis}

Qualitative analysis was used in order to illustrate the words that participants most frequently used. Including the words which were frequently used by the participants allowed for greater support in the validity and reliability of the analysis. For the open-ended question "please think about nature: what words come to mind," qualitative analysis began by sorting the children's and parents' responses into seven different categories: emotion words, animal words, plant words, element words, descriptive words, action words as well as the total number of words that each participant took to answer an individual question. For specific descriptions of the meanings to these categories, please refer to Appendix E. There are two main reasons as to why these seven word categories were chosen to analyze the participant responses. First, sorting responses into categories will provide a clearer and more organized manner in interpreting the data, and seeing whether participants in the mountainous regions do consider themselves to be more at one with nature. For instance, words that fit into the emotion and action category would illustrate that participants have more experience and an emotional bond with nature, as opposed to the words that are expressed in the plant or descriptive category. Secondly, these word categories were adapted from Rinkoff and Gaston (2008) previous research of "The child's proximity to mountains as a predictor of environmental intimacy: Implications for stewardship." 
To find out what words were most frequently used by children and parents, a word document was used to chart the number of times each word was used in each area. The chart included three columns: word column (name of word), participant number that used the following word, and the number of times that word was used. The total frequencies were noted for all the children and parents. From that, the top 3 most used words were tallied for both parents and children in each area as well as all areas together. For a sample of the chart please refer to Appendix $K$. This technique was used to discover which words were the most popular within the parent and child population in each area, as well as the overall popularity of words that were used in both areas. The words were also directly quoted to provide more comprehensive examples to support the quantitative data, which is predominant in a mix-method study (Creswell, 2005).

\section{Quantitative Analysis}

Open-ended questions such as "please think about nature: what words come to mind," were also analyzed quantitatively. This provided various dimensions for understanding the open-ended questions. Additionally, analyzing the open-ended questions both qualitatively and quantitatively allowed for greater support in the validity and reliability of the analysis. In other words, this processes ensured that each word is placed in the correct category without errors, especially in the difficult words. If an error occurred, the researcher reviewed the answers and placed the word in the appropriate category. Overall, this method not only allowed for a 2-way perspective of the qualitative data, but also ensured validity of qualitative data analysis.

SPSS was used for the quantitative analysis of the open-ended and closed-ended survey questions. The Statistical Package for the Social Sciences, or in other words, SPSS is a statistical program to specifically assist in analyzing quantitative data (Creswell, 2005). For the open-ended questions, words were placed under their labeled category and then counted for each participant. 
For instance, participant 45 in the urban area was noted as having 3 emotion words, 2 animal words, 1 plant word, 1 element word, and 3 action words, with an overall count of 11 words that $\mathrm{s} /$ he has used for the question. Once categorized, both descriptive and inferential statistics were used. For the descriptive statistics, the word totals and averages were calculated. Inferential statistics was then applied to ensure significant results for valid generalizations. Since the measurement levels include nominal/categorical scores T-Test Independent Sample was calculated between the mountainous and urban areas. In order to examine if there is a relationship between the types of words that were used between the parents and children, T-Test Correlations were calculated between children and their parents. This was completed by merging the parent and child SPSS spreadsheets together. Then, T-Test significance was measured between each word category for both locations (e.g., parent emotion words versus child emotion words and so forth).

Closed- ended questions, including "how much a part of nature do you feel" and "how much a part of nature do you feel the place where you live is," were calculated using the ChiSquare technique. Each multiple-choice answer was given a number from 1 to 4 and then filled in on an SPSS spreadsheet for valid conclusions. This identified whether there was a difference between the participants living in the mountainous and urban areas in the way they feel about themselves and their location in regards to nature. By examining these results, it also enabled the principal investigator to find out whether the parents and children have similar results. Lastly, the significance value was always calculated as One-Tailed Test of Significance for all SPSS calculations since the previous research indicated a possible direction for the results (Creswell, 2005). 


\section{Merging the Open and Closed-Ended Data}

After a separate analysis, both quantitative and qualitative data were merged together to make final conclusions. This enabled the researchers to support the children's closed-ended survey choices with their open-ended explanations (Creswell, 2005). Therefore, it allowed for the statistical trends to be supported by the qualitative variables, ensuring consistent and validated results (Creswell, 2005).

\section{Validity and Reliability}

There are various possible threats to the validity and reliability of the research tools. In order to ensure that the participant survey reveals consistent and comprehensive results that answer to the research questions, expert counseling was completed with the researcher's supervisor who has strong experience in early childhood study research. This ensured that the research questions fully extract answers that identify with the main research purpose. Furthermore, open-ended and close-ended research questions were asked in order to gain insightful information for the participants. Identical copies of the surveys were distributed to each participant. This provided consistency in data collection, ensuring validity and reliability (Creswell, 2005). Lastly, the open-ended questions were analyzed both qualitatively and quantitatively, providing a doublechecking technique that ensured that each word was placed in the correct category without errors. This technique therefore provided greater support for validity and reliability of the methodology.

\section{Ethics and Human Relations}

There are possible human ethical issues that have the possibility to arise through the process of this research study. As in any research study, participants have the potential to feel uncomfortable participating due to the risk of their names or identities being disclosed. However, since neither names nor any questions were asked that have the potential to reveal their identity, 
this is very unlikely. Furthermore, young children participating in research studies might have the possibility of being unaware of issues surrounding the research project, which goes against their rights as research participants. In order to prevent this, such issues and clear explanations were addressed in the consent forms. After completing the data collection, there is the potential of data being revealed to the public, exposing the collected data and participant's identities (Hogan \& Greene, 2005).

Several precautions were taken prior to beginning the data collection process to avoid these ethical issues. The collected data were coded by numbers and the participant names, as well as the school-site names, were kept anonymous. This allowed confidentiality for the participants, keeping their identities private. Further, the survey questions were non-threatening; the participants also had the opportunity to omit a question or withdraw at any point during the data collection process without penalties, providing them with the ethical freedom and safety that they are entitled to hold. Finally, the recruitment consent forms were available to the school officials, parents, as well as participants, that clearly state the voluntary nature of this study as well as the ethical considerations described above. This is especially crucial for the younger participants, where they may be at greater risk of being overlooked (Hogan \& Greene, 2005). Upon finishing, data was stored in a safe and private place.

\section{Findings}

\section{What is the impact of location on children's thoughts and feelings towards nature?}

The major component of this analysis consisted of calculating children's responses to the "name the words that come to mind when thinking of nature" survey question. As previously described, these responses were categorized into 7 categories: emotion, animal, plant, element, descriptive, action and total words that participants used in each area. From there, comparisons 
were completed by tallying the total amount of words in each area, and noting the top 3 words used. Additionally, comparisons were made by conducting $T$-Test statistics between the mountainous and urban areas to find out if the results are statistically significant. As for the closed-ended questions of "how much a part of nature do you feel you are" and "how much a part of nature do you feel the place where you live is," Pearson Chi-Square analysis was used.

\section{Top Three Words used in Each Location}

Overall, results indicate that the participating children in both areas together used tree most frequently, with 47 counts. With that, animals (with 42 counts) and flowers (with 23 counts) came in at second and third place. As indicated below in figure 1, the top three words in each area were quite similar. All three words were listed as the most popular, however, placed in different orders. As animal was in first place in the urban area, it went down to second place in the mountainous regions. On the contrary, tree was placed second in the urban area and was moved up to first in the mountainous regions. Finally, flower stayed as third in both areas.

\begin{tabular}{|l|l|}
\hline \multicolumn{2}{|c|}{ City/ Urban Area } \\
\hline WORD & NUMBER OF COUNTS \\
\hline Animal & 23 \\
\hline Tree & 20 \\
\hline Flower & 18 \\
\hline
\end{tabular}

\begin{tabular}{|l|l|}
\hline \multicolumn{2}{|c|}{ Mountainous Area } \\
\hline WORD & NUMBER OF COUNTS \\
\hline Tree & 27 \\
\hline Animal & 26 \\
\hline Flower & 10 \\
\hline
\end{tabular}

Figure 1: Top 3 Words in Each Area for Children

T-Test on Open-Ended Questions. T-Test inferential statistics were completed on both regions for each word category. As shown in figure 2 (refer to the appendix for complete chart), results indicate a significance of $\mathrm{p}=0.05$ for the "emotion" words with the average significantly higher in the mountainous regions than the urban region. Additionally, it is concluded that there is a strong significance of $\mathrm{p}=0.03$ for the "descriptive" category in the urban area in comparison to the mountainous regions. Therefore these results illustrate that children in the mountainous 
regions expressed more "emotion" words (such as beautiful, amazing, or free) than the children living in the city. However, children in the city used more "descriptive" words (such as tall, big or green) in comparison to children living in the mountainous regions. Otherwise, there are no significant differences between the types of words used in each location.

Children's T-Test Results (Mountain vs. City Environment)

\begin{tabular}{|c|c|c|c|c|}
\hline $\begin{array}{l}\text { Type of } \\
\text { Words }\end{array}$ & Areas & $\begin{array}{l}\text { N (Number of } \\
\text { Words) }\end{array}$ & Mean & $\begin{array}{c}1 \text { - Tailed } \\
\text { Significance } \\
\text { Level }\end{array}$ \\
\hline Emotion & $\begin{array}{l}\text { Mountain } \\
\text { City }\end{array}$ & $\begin{array}{l}15 \\
11\end{array}$ & $\begin{array}{l}2.00 \\
1.00\end{array}$ & 0.05 \\
\hline Animals & $\begin{array}{l}\text { Mountain } \\
\text { City }\end{array}$ & $\begin{array}{l}41 \\
27\end{array}$ & $\begin{array}{l}1.76 \\
1.74 \\
\end{array}$ & 0.48 \\
\hline Plants & $\begin{array}{l}\text { Mountain } \\
\text { City }\end{array}$ & $\begin{array}{l}39 \\
28 \\
\end{array}$ & $\begin{array}{l}2.08 \\
2.00\end{array}$ & 0.37 \\
\hline Elements & $\begin{array}{l}\text { Mountain } \\
\text { City }\end{array}$ & $\begin{array}{l}16 \\
22 \\
\end{array}$ & $\begin{array}{l}1.44 \\
1.64 \\
\end{array}$ & 0.24 \\
\hline Descriptive & $\begin{array}{l}\text { Mountain } \\
\text { City }\end{array}$ & $\begin{array}{l}18 \\
11 \\
\end{array}$ & $\begin{array}{l}1.33 \\
2.00 \\
\end{array}$ & 0.03 \\
\hline Action & $\begin{array}{l}\text { Mountain } \\
\text { City }\end{array}$ & $\begin{array}{l}5 \\
5\end{array}$ & $\begin{array}{l}1.20 \\
1.20\end{array}$ & 0.5 \\
\hline Total & $\begin{array}{l}\text { Mountain } \\
\text { City }\end{array}$ & $\begin{array}{l}63 \\
40\end{array}$ & $\begin{array}{l}6.16 \\
6.63 \\
\end{array}$ & 0.32 \\
\hline
\end{tabular}

Figure 2: Children's T-Test Results

Chi-Square Closed-Ended Questions. Pearson Chi-Square analysis of the closed-ended questions revealed insignificant ( $p>0.05$ ) results for the children's question of "how much a part of nature do you feel you are." As chart 1 illustrates below, there was not a significant difference between the answers that children gave in the urban and mountainous regions: location did not play a major role in establishing a child's perspective towards their own relationship with nature in this particular sample. However, results changed for the question "how much a part of nature do you feel the place where you live is" where the chi-square results indicated a strong significance $(\mathrm{p}=0.00)$. Specifically, $45 \%$ (28 out of 62 ) children in the mountainous regions 
stated that their home surroundings are completely a part of nature and $41 \%$ (26 out of 62 ) stated that their home surroundings are very much a part of nature. This contrasted with the children living in the urban area, where the majority $(53 \%, 21$ out of 40$)$ of the children considered their home surroundings to be a part of nature a little bit. As these results indicate, children living near the mountains feel that their surrounding environment is indeed related to nature significantly more than children located in urban areas.

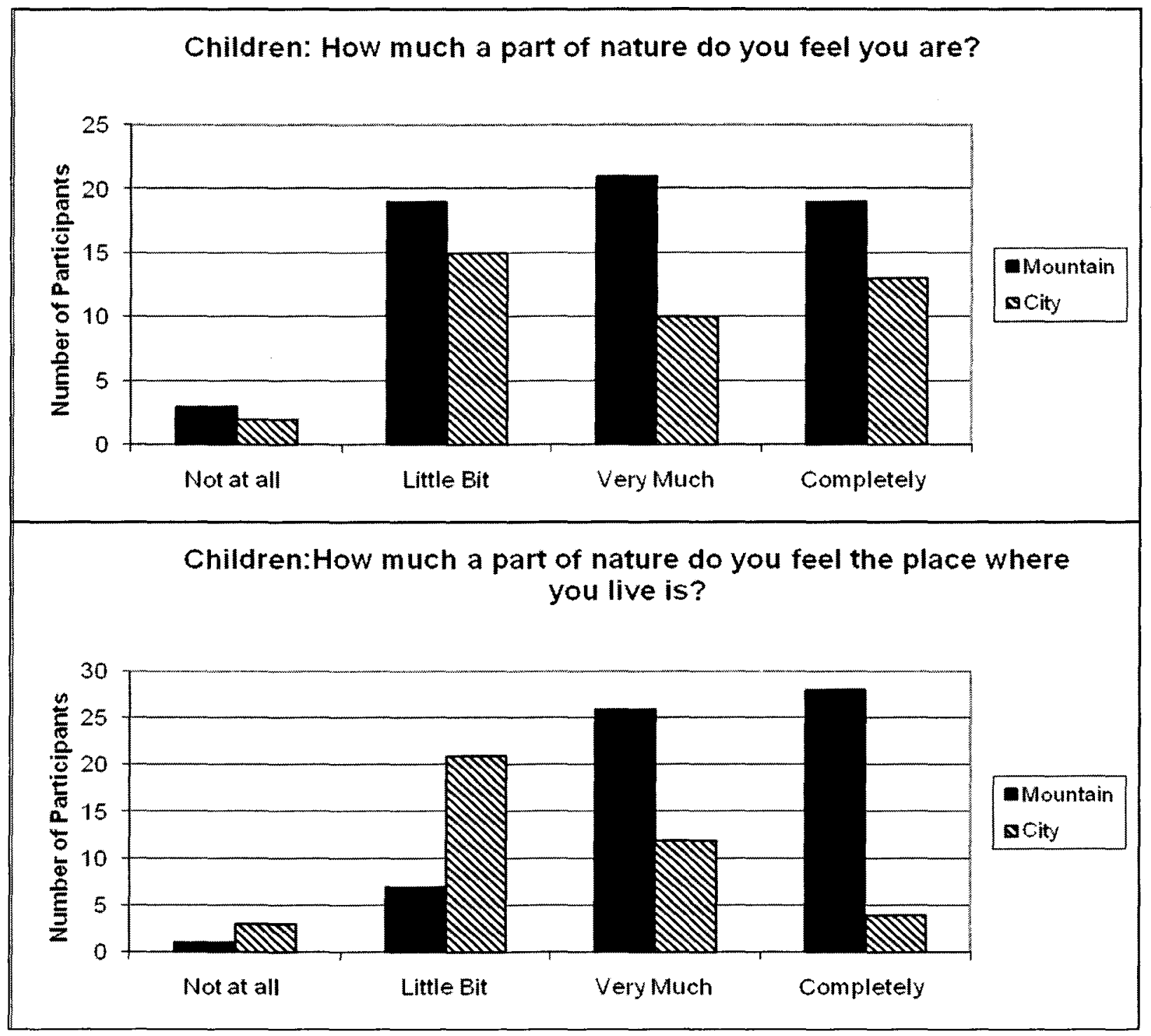

Chart 1: Results from the Closed Ended Questions 


\section{What is the impact of location on parents' thoughts and feelings towards nature?}

The same method of analysis was followed when measuring the impact of location on parents' thoughts and feelings regarding nature. Qualitative comparisons were formed by tallying the total number of words in each area, and noting the top three most frequently used words in a Word document in addition to calculating T-Test statistics. Just as for the children's closed-ended questions, Pearson Chi-Square analysis was used for the questions, how much a part of nature: "do you feel you are" and "do you feel the place where you live is."

Top 3 Words used in Each Location. In terms of the question: "words that come to mind when thinking about nature," the number one word that was noted in all areas together is animals with 21 counts. Following, trees (with 18 counts) and beautiful (with 14 counts) were stated. Although beautiful was noted as the third most frequently used word, it is close to the other words which were frequently used by the parents. Overall, as figure 3 illustrates, the parents did not show a pattern when comparing the most frequently words used in the three areas. The parents in the urban area most frequently mentioned the word beautiful while thinking about nature. Instead, parents in the mountainous regions used tree the most frequently. It is also important to note, that as seen in figure 3, free and life were tied as the third most frequent word used by parents in the urban area.

\begin{tabular}{|l|l|}
\hline \multicolumn{2}{|c|}{ City/ Urban Area } \\
\hline WORD & NUMBER OF COUNTS \\
\hline Beautiful & 13 \\
\hline Peace & 6 \\
\hline Free and Life & Both counted 3 \\
\hline
\end{tabular}

\begin{tabular}{|l|l|}
\hline \multicolumn{2}{|c|}{ Mountainous Area } \\
\hline WORD & NUMBER OF COUNTS \\
\hline Tree & 14 \\
\hline Animal & 12 \\
\hline Birds & 6 \\
\hline
\end{tabular}

Figure 3: Top 3 Words in Each Area for Parents 
T-Test on Open-Ended Questions. Figure 4 displays the results for the condensed T-Test

calculations for the parental participants (see appendix for complete chart). As shown, there were statistically insignificant $(p>0.05)$ results while comparing the average of words used in both regions. This signifies that location does not play a role in the way a parent in this sample thinks about nature. In reference to the "action" category, results could not be obtained due to the limited number of words that all parents used in that category.

Parent's T-Test Results (Mountain vs. City Environment)

\begin{tabular}{|c|c|c|c|c|}
\hline Type of Words & Areas & $\begin{array}{c}\text { N (Number } \\
\text { of Words) }\end{array}$ & Mean & $\begin{array}{c}1 \text { - Tailed } \\
\text { Significance } \\
\text { Level }\end{array}$ \\
\hline \multirow[t]{2}{*}{ Emotion } & Mountain & 28 & 2.00 & \multirow[t]{2}{*}{0.32} \\
\hline & City & 19 & 1.84 & \\
\hline \multirow[t]{2}{*}{ Animals } & Mountain & 19 & 1.42 & \multirow[t]{2}{*}{0.29} \\
\hline & City & 17 & 1.29 & \\
\hline \multirow[t]{2}{*}{ Plants } & Mountain & 20 & 1.90 & \multirow[t]{2}{*}{0.37} \\
\hline & City & 17 & 2.00 & \\
\hline \multirow[t]{2}{*}{ Elements } & Mountain & 23 & 1.70 & \multirow[t]{2}{*}{0.31} \\
\hline & City & 14 & 1.93 & \\
\hline \multirow[t]{2}{*}{ Descriptive } & Mountain & 33 & 1.82 & \multirow[t]{2}{*}{0.20} \\
\hline & City & 25 & 2.12 & \\
\hline \multirow[t]{2}{*}{ Action } & Mountain & 2 & 3.00 & \multirow[t]{2}{*}{$\mathrm{n} / \mathrm{a}$} \\
\hline & City & 1 & 3.00 & \\
\hline \multirow[t]{2}{*}{ Total } & Mountain & 52 & 7.75 & \multirow[t]{2}{*}{0.23} \\
\hline & City & 36 & 5.97 & \\
\hline
\end{tabular}

Figure 4: Parents' T-Test Results

Chi-Square Closed-Ended Questions. For the closed-ended question of "how much a part of nature do you feel you are," the results showed insignificant $(p>0.05)$ differences between the answers that the parents in the urban and mountainous areas gave, illustrating that location does not play a role in a parents' perspective towards their environmental surroundings. As for the second question, "how much a part of nature do you feel the place where you live is," there was a strong significance $(p=0.00)$ in the results. Specifically, $62 \%$ (31 out of 50$)$ parents in the mountainous regions stated that their home surroundings are very much a part of nature and $30 \%$ 
(15 out of 50) stated that their home surroundings are completely a part of nature. This contrasted with the parents located in the urban area, where the majority of $67 \%$ ( 24 out of 36 ) of the parents considered their home surroundings to be a part of nature a little bit. These results showed that location plays a role in a parent's perspective towards the naturalness of their living environment. Detailed results are also illustrated in chart 2 below.

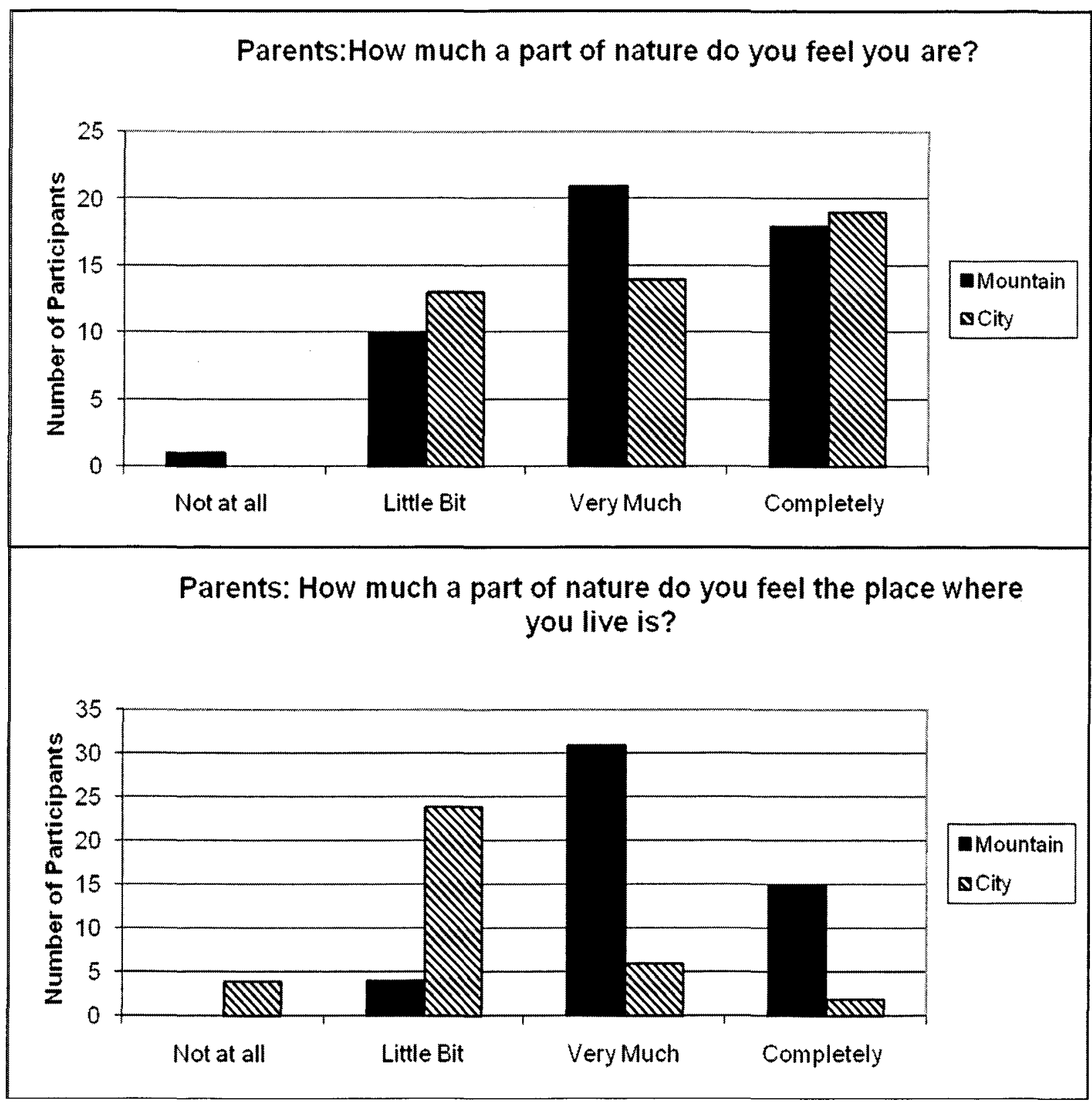

Chart 2: Results from the Closed-Ended Questions 


\section{What are the differences between children's and parents' thoughts and feelings towards}

nature?

In order to compare the children's and parents' results, the data were analyzed in three different ways. First, word frequencies were compared in order to find out if the parents and children used the same words when answering the question "name words that come to mind when thinking about nature." This was completed by Pearson T-Test correlations by merging the parent and child data together and comparing the word categories (ex. Child emotion words vs. Parent emotion words, etc). Additionally, qualitative word charts of the top three most frequent words were compared to examine whether there are similarities between the word choices used by parents and children. Lastly, Chi-Square results for the closed ended questions were compared, drawing out any similarities and differences.

Comparison of Open-Ended T-Test Scores (Word Frequencies). The Pearson T-Test was used to compare the word frequencies between the parents and children from the open-ended question: "name words that come to mind when thinking about nature." By merging the parent and child data together onto one SPSS spreadsheet, the overall sample as well as samples from the mountainous and urban area were analyzed. Results from the mountainous environment illustrated that there is a significance $(\mathrm{p}<0.005)$ between the children and parents living in the mountainous environment for the "descriptive" words. Furthermore, significance of $p<0.05$ was also present for the total number of words used. This illustrates that the parents as well as children used the same number of "descriptive" and "total number" of words used in the mountainous environment. As for the participants living in the urban location, there was a significant $(\mathrm{p}<0.05)$ correlation between the parent and child sample for the "plant" category. This signifies that children and parents in the urban area used the same number of words 
categorized as "plants." As for the overall parent and child population in both areas, there was a significant correlation in the "plant" category $(\mathrm{p}=0.005)$, "descriptive" category $(\mathrm{p}=0.005)$, as well as in the "total number" of words $(\mathrm{p}<0.05)$.

\begin{tabular}{|l|l|l|l|}
\hline \multicolumn{2}{|c|}{ Urban Area } & \multicolumn{2}{c|}{ Urban Area } \\
\hline Word & Frequencies & Word & Frequencies \\
\hline Beautiful & 13 & Animal & 23 \\
\hline Peace & 6 & Tree & 20 \\
\hline Free and Life & Both counted 3 & Flowers & 18 \\
\hline
\end{tabular}

\begin{tabular}{|l|l|l|l|}
\hline \multicolumn{2}{|c|}{ Mountainous Area } & \multicolumn{2}{c|}{ Mountainous Area } \\
\multicolumn{1}{|c|}{ Parents } & \multicolumn{2}{c|}{ Children } \\
\hline Word & Frequencies & Word & Frequencies \\
\hline Tree & 14 & Tree & 27 \\
\hline Animal & 12 & Animals & 26 \\
\hline Birds & 6 & Flower & 10 \\
\hline
\end{tabular}

Chart 3: Comparison of Parent and Children Word Frequencies

Open-Ended Top 3 Most Frequent Words Used-Comparison. In order to qualitatively compare the top three words used by parents and children, the two words charts were placed side-by-side (as seen in chart 3). Interestingly, in the mountain regions, both children and parents used the same top 2 words to describe nature. The words included tree ( with 27 counts for children and 14 for parents) and animal (with 26 counts for children and 12 for parents). These similarities were not found for the participants living in the urban area.

Chi-Square Comparisons of the Closed-Ended Questions. Since the survey asked parents and children the same closed-ended questions, comparisons between the two sets of participants could be made. For this, Chi-Square results were placed side-by-side for evaluation. Exact results were found amongst the two questions between parents and children. For the first 
multiple-choice question: "how much a part of nature do you feel you are," all of the participants had insignificant results ( $p>0.05)$. This illustrates that location did not play a role in this sample's viewpoint about their personal relationship with nature. Results changed for the second multiple-choice question of "how much a part of nature do you feel the place where you live is." The children's as well as the parents' data showed highly significant results of $p=0.00$, meaning that location does play a major role in the samples feelings about their natural environment. Specifically, both parents and children in the mountainous areas found that they either felt their surrounding environment was: very much a part of nature ( $62 \%$ of parents, $42 \%$ of children) and completely a part of nature ( $30 \%$ of parents, $45 \%$ of children).

\section{Discussion}

The aim of this research study was to examine how location has an impact on a child's and parent's thoughts and feelings regarding nature. In addition this research examines whether parents have an influence over children's viewpoints about nature. In order to do so, a sample of 192 participants in the mountainous and urban landscapes was surveyed by open and closedended questions, which were analyzed using the mix-method design. The following discussion is divided into two sections, including: impacts of location on children's and parents' thoughts and feelings regarding nature and differences between children's and parents' thoughts about nature.

\section{Impacts of location on children's and parents' thoughts and feelings towards nature}

As a result of past research studies (Bonnett \& Williams, 1998; Wells \& Lekies, 2000; Van Petegem \& Blieck, 2006; Zaradic \& Pegams, 2007), it was hypothesized that geographical location has an effect on the ways children and parents think about nature. Specifically, 
participants living in the mountainous locations will be more at one with nature, relating themselves with nature more so than the participants living in urban locations. Additionally, children's and parents thoughts and feelings regarding nature will correlate with each other. Therefore, the parents will display similar responses to their children's on the survey questions. However, results presented slightly dissimilar conclusions for both parents and children.

Results showed that children in the mountainous region presented more emotion words and children in the urban region presented more descriptive words. However, there were no significant differences with the other categories. The children in both mountainous and urban areas used the same top words to describe nature in different orders, which were a part of the plant and animal category (e.g., "tree," "grass," "bird," or "squirrel"). Although children living in the mountainous regions felt that their environment was a part of nature, results showed that location did not play a role when considering themselves to be a part of nature. As for the parents, results illustrated that there were no significant differences in any word categories, illustrating that location does not play a role in the way parents think about nature. In reference to the action category, results could not be made due to the limited number of words. Although there was no significant differences between how much a part of nature they feel they are between the two areas, the parents in the mountainous areas did find their communities to be completely a part of nature.

Children in the mountainous areas expressed a greater number of words in the emotion category signifies a couple of things. Firstly, children in the mountainous regions have more contact with nature, and therefore could express more feeling that they experience while being in the natural environment, such as feelings of being "happy" and "relaxed". In contrast, children 
living in urban environments may have restricted contact with the natural world and therefore may not associate emotions with nature.

This further could be verified by the number of descriptive words that children in urban areas instinctively thought of when thinking about nature. Descriptive words, such as tall, big, or green were seen more predominant in the urban sample. This could be explained by the lack of contact children in the urban region have with nature. Instead of having the experience in a natural environment, children living in urban areas rely more on their school's curriculum and media to teach them about the environment (Bonnett \& Williams, 1998). Therefore, it is understandable for them to name more descriptive words, such as big or green, to explain nature. According to Bonnett and Williams (1998), children associate a variety of emotions to nature in accordance to where they live. Their study reveals that children living in the natural environment mostly express positive feelings of happiness and calmness. However, Bonnett and Williams (1998) also found that children may also associate negative feelings of boredom or fear to nature due to the social influences of media, television and other technological aspects. Similar results could be found in Zaradic and Pegams (2007) study of the media's influence over children's perceptions about nature, where they illustrated that children may relate nature to the feelings of boredom and danger.

The survey question: how much a part of nature do you feel aimed to find out if a child perceives him/her self as being one with nature, and was hypothesized that children in the mountainous areas would relate themselves with nature more so than the children living in urban locations. However, results illustrated that location did not play a significant role in the children's responses to this question. This is inconsistent with previous research studying the impacts of geographical locations on a child's attitude and perspectives about nature. For 
instance, Van Petegem and Blieck (2006) studied environmental worldviews between children living in industrialized and non-industrialized counties. The results of this study showed that children in Zimbabwean communities feel separate from nature and displayed more humandominance viewpoints. In contrast, children in Belgium communities consider themselves more connected with nature in the human-nature equality viewpoint (Van Petegem \& Blieck, 2006).

Bonnett and William (1998) showed that media and other forms of technology increasingly affect a child's perception about nature. By interviewing several lower-elementary school students, they found that some of the children did not regard humans as being a part of nature and suggested that media influences play a large role in this perspective (Bonnett \& Williams, 1998). As opposed to Van Petegem and Blieck's (2006) study of comparing nonindustrialized communities in Zimbabwe and industrialized communities of Belgium, this present study solely focuses on industrialized locations. Therefore, all of the children in this study had the same levels of accessibility to the media, which is shown to largely play a more significant role in a child's upbringing (Bonnett \& Williams, 1998; Pergams \& Zaradic, 2006; Zaradic \& Pergams, 2007). Since there was a significant difference between the mountainous and urban environments when answering the question, "how much a part of nature do you feel the place where you live is," it illustrates that children have awareness of how natural their home communities are. Therefore, although the children in the sample have an awareness of their natural environments, it still does not fully impact their own viewpoints of their personal connection with nature.

Although there were differences between the types of words that the children used in both types of areas, this was not so in the parent sample, therefore refuting the hypothesis for them. The findings illustrate that parents in mountainous and urban environments did not differ in their 
mentality towards nature. According to Wells and Lekies (2006), adults who had direct experience with the nature prior to age 11 were more likely to become more connected towards the environment. Particularly, results of their study showed that participants who have experienced more nature-related activities, such as hiking, swimming or nature walks on a consistent basis, were shown to maintain more pro-environmental and emotional connections with nature later on in life (Wells \& Lekies, 2006). By following these conclusions, it would be expected that parents in the mountainous regions express more emotion and action words when thinking about nature more frequently than parents living in urban settings. Instead, there were no significant differences between the types of words that parents in both urban and mountainous regions expressed.

According to Wells and Lekies' (2006) study, there may be several reasons for this inconsistency. Parents in the urban setting may have experienced living in nature-rich environments in their childhood years. Since the surveys from this particular study did not question parents about their upbringing and past experiences, early influences could not have been further explored. Likewise, it is not clear whether parents located in the mountainous regions had those types of early age experiences with nature, resulting in insignificant results. Therefore, it would have been beneficial to question parents about their past experiences with nature and childhood upbringing. Furthermore, adding more questions to measure the parent's viewpoint about nature would be beneficial. For instance, establishing open-ended questions that would allow the parents to explain their perspectives and feelings towards nature would allow for greater clarification for their responses. By providing more opportunities for self-explanation and ideologies towards the natural environment, it would allow for the results to be expanded and explained further. 


\section{Differences between children's and parents' thoughts and feelings regarding nature}

One of the components of this study was to find out whether parents and children have similar thoughts and feelings towards nature, and whether parental influences play a dominant role in a child's attitudes towards nature. According to the hypothesis, children's and parents' thoughts and feelings towards nature would correlate with one another. Therefore, participants in the mountainous regions would display higher connections to nature in comparison to the participants living in the urban area.

Results illustrated that both parents and children in the mountainous environment used similar amounts of descriptive and total number of words. As for the rest of the words, including emotion, animal, plant, element and action words, there were no similarities between parents' and children's responses. Furthermore, the participants in mountainous regions used the same top- two words to describe nature: animal and tree. As for participants in the urban environment, parents and children also both used similar amount of plant words to describe nature. No similarities were found for the rest of the words (emotion, animal, element, action, descriptive and total number of words) between the parents and children in the urban regions. For the closed-ended questions, the children's and parents' responses correlated with one another: location does not play a role when considering themselves a part of nature, and in comparison to the urban sample, all participants in mountainous regions agree that their location is a major part of nature.

Previous studies have shown that parental influences are a strong mediator of a child's nature perspectives (Alp et al, 2008; Devine-Wright et al, 2004; Hyun, 2005). Such parental influences are caused by accessibility of resources, modeling appropriate behaviour and nature exposure. It was also noted that participants in the mountainous region used the same top two 
words (animal and tree). In accordance with previous research, these results showed that the majority of parents and children associate nature with similar words, proposing that parents have an influence over their children's nature attitudes. However, results varied for the type of words that parents and children used in all areas. As presented earlier, findings indicate that results from parents and children in mountainous areas only correlated in two out of seven word categories (descriptive and total amount), and only with one category in the urban area (plant). These overall results signify that, although parents could influence a child's nature perspective, it was not to the extent that it was expected to be. As for the closed-ended questions, it is apparent that the answers that the parents and children gave in each region are in agreement. It is concluded that both parents and children in the mountainous regions feel that their environment is either completely or very much a part of nature in comparison to the urban sample. This illustrates that children and parents have similar opinions about their surrounding environment. These results could have several possible explanations. First, parents and children could have a different use of vocabulary. As Hyun (2005) mentioned, children and adults have different mental processes. It is apparent that children's vocabulary is still developing and that children do not have the word experiences that adults hold. Therefore, their associations with nature could still differ (Hyun, 2005). Such indicators of children's mental processes could be seen in these results. Since the participants in this study are still in their developing years, their vocabulary could differ from their parents. Further, according to the past literature, other influences could potentially impact a child's sense of nature, which could differentiate their attitudes from their parents. As discussed, media influences, peers and education could have a significant role in a child's beliefs and perspectives. As children spend an increasing amount of time in school and using technology, it could be suggested that these mediating influences could 
have stronger effects on a child's perspectives which their parents may not have access to. Lastly, the results of this particular research are not clear as to whether parents influence children, or vice versa. An important suggestion for further research would be to specifically ask the participants about where they attain their knowledge about nature. This will clearly provide the researcher with an idea of where the children as well their parents receive their nature knowledge from and what influences their thoughts and feelings regarding nature.

\section{Limitations of the Study}

Due to time constraints and a lack of resources and funding, the research study presents some limitations. There are some limitations of this research study which should be recognized: Limited Number of Questions. The data analysis was based on a total of three questions for parents and three questions for children. Since the data collection was taken from a survey that was based on children's and parents' relationship with mountains, only a limited number of questions could be taken that were relevant to nature. Therefore, a set of more diverse questions is needed in order to improve the research study. For instance, questions that would explore a participant's nature perspectives would be beneficial (e.g., 'do you think nature is important?'), as well as questions that deal with behavioural influences (e.g., 'where do you learn about nature?').

A Reflexive methodology. Since the data was collected from a previous research study, it contained limited number of the type of questions, which only consisted of multiple- choice and open-ended questions. In order to gain more detailed and insightful data from a mix-method and reflexive methodology, a greater variety of questions is needed, such as drawings and conducting individual or group interviews.

Participants. Due to the fact that the research survey was voluntary, there were uneven numbers of participants between the two areas, as well as between the parents and children. Therefore, 
this could skew the data in such a way that it will result in an unrepresentative number of participants in each area.

\section{Recommendations for Future Research}

Based on these illustrated results as well as the limitations that were presented, additional research studies need to be conducted. The sample was based on urban and mountainous regions, and therefore reflected the options that participants had in the mountainous environments. For future research, it would be beneficial to explore the perspectives that children and parents have about nature in sub-urban areas, in comparison to the urban cities. A different location would encourage gaining more data about perspectives about nature. As stated in the limitations above, it would be beneficial to construct a survey that is entirely based on nature which could be distributed to the urban and sub-urban samples that is composed out of variety of open and closed-ended questions dealing with nature attitudes. This, in turn, will provide comprehensive results on the attitudes that parent and children have about natural environments.

The results of this current research project revealed the thoughts and feelings that parents and children have regarding nature in mountainous and urban regions. It however did not explore how the school's curriculum and teachings served as a factor in developing these ideologies.

Therefore, an important future study would be to explore the role that environment education is playing for children in terms of environmental attitudes. For instance, comparing educational systems that focus their daily philosophies on nature education, such as Steiner-Waldorf education, would be beneficial to discovering if nature education is significant, and to what extent. By comparing the ideologies of children, parents and teachers attending nature-focused schools such as Waldorf in urban and suburban regions, the comparisons of the importance of nature-education could be revealed. 
The sample of the present study only focused on children aged from 6 to 12 years of age, as well as their parents. In order to investigate whether there is a difference between the natureattitudes of younger children, future research needs to expand across younger children. Such research would explore if younger children have awareness about the natural environment in terms of where they live. Additionally, it would also be beneficial to investigate whether there are differences of attitudes between genders. The results of this current study revealed the nature attitudes of parents and children, as well as the influence of location. Therefore, extending the investigation to explore the viewpoints between boys and girls would have a benefit to see whether it has similar effects on both genders.

The discussion revealed that influences of mental processes and different vocabulary levels between the parents and children impacted survey responses. Building on this, it would be advantages for future research to examine the developmental trends in the relationship between responses of children of difference ages and their parents' responses. Lastly, since this present study was focused on children's attitudes towards nature, it would be valuable to examine the perspectives that children have on environmental issues, such as recycling and climate change, and if geographical location has an impact on a child's perspectives.

This study serves as an important guide for parents, educators as well as policymakers. It underlines the importance of direct-nature experiences that children need to acquire soon in their early lives. Further, it states the impact that physical location as well as parental guidance has on children's thoughts and feelings regarding to nature. In order to improve the relationship that children living in urban settings have with nature, curricula need to be modified in order to include positive, direct-experiences with nature. Placing emphasis on teaching children about the significance of nature in daily life, will shift a child's thoughts and feelings 
towards nature, in addition to encouraging strong nature connections to develop. Due to the overwhelming requirements and pressures that are placed on teachers, they may not have the extra time to research information on nature. Therefore, guides and resources need to be directly provided that suggest such nature activities for children. A selection of examples of games is provided in the resources section.

It is also important to remember that children need unstructured play in nature. As opposed to structured activities, unstructured play will allow the freedom for children to become explorers of their surroundings, cultivating relaxation, curiosity and the ability to become teachers of their own learning. Policies should be put in place for more opportunities such as this to exist. Equally important, teachers should create a balance between indoor and outdoor learning for their students. Finally, it is also crucial for parents to provide numerous opportunities for their children to play outdoors, such as partaking in cost-free activities such as walks or simply spending time outdoors.

\section{Conclusion}

By analyzing the perspectives of children and parents living in urban and mountainous environments, this research study examined if location has an influence on a child's and parent's perspectives towards nature, as well as discovering if there is a relationship between parent and child thoughts and feelings regarding nature. Results revealed that, although there were some inconsistencies, location does play a role between the emotion and descriptive words that children use. Specifically, children in the mountainous regions used a higher amount of emotion while thinking of nature, whereas children in the urban region were more descriptive. As for parents, it was shown that location does not play a role in the type of words that they have expressed. However, it was concluded that both parents and children in the mountainous regions 
felt that their immediate environment is more fully a part of nature when compared to the urban sample. Lastly, there was a correlation between the descriptive and total number of words for the parent and child sample.

The results of this study highlight the importance of the presence and first-hand experience of the natural world in a child's nature- attitude formation, forming practical recommendations for parents, educators as well as policy- makers. Furthermore, although there are many intervening factors, parents still seem to have an influence over their child's nature attitudes. However, future studies should include examining the influences that nature-based educational programs have on children, in addition to investigating the role that age and gender play in shaping perspectives and attitudes towards nature. As previous literature proves, having positive perspectives about nature is crucial in the childhood stage not only for maintaining proenvironmental attitudes in the future but also for physical and psychological wellbeing (HaluzaDelay, 2001; Hamilton, Klebanoff \& Sharp, 1991; Wells \& Evans, 2003; Zeece \& Wells, 2007). Once children are involved in the natural surroundings, they develop a deeper sense of selfunderstanding, appreciation and problem-solving skills, which is crucial for a healthy child development. As Korhonen and Lappalainen (2004) state, "concern for the natural world is shaped through social learning. Interactions with the living environment and other people in the early childhood are the most important factors in shaping opinions" (p.196). 


\section{Appendix A}

Copy of Introduction Flyer

May 18, 2006

Dear Children and Parents/Guardians,

Gabriel Epstein, a retired elementary school teacher in Toronto, and I are beginning a research project entitled "Children and the Mountain Environment: Exploration and Education."

We would like to see if where children live and how old children are affect what they know about mountains, wilderness, and nature. We are also asking parents/guardians and teachers questions about these topics.

We hope to use this information to help teachers teach about mountains and mountain wilderness in a better way. We also hope to learn more about what people know about the mountains and how they feel about them. We will use the information to write some articles and develop teaching materials.

Please take a look at the papers in the envelope to learn more about this project. There are two papers for the child in elementary school and two papers for one of their parents or guardians.

Please note that the schools involved will not be named in anything we write or say and that all the information collected will be anonymous - no names will be used.

We hope you will be interested in participating in our project. If you have any questions, please contact Robert Rinkoff through the school office (telephone number) or by e-mail at rrinkoff@ryerson.ca. The project has been approved by Ryerson University's Research Ethics Board and by the school superintendent and the Board of Education.

Please return the surveys - and, if you are agreeable, the tear-off Follow-up Discussion Group Permission slip - sealed in the envelope, either to your teacher or to the school office by May 25. If you are returning the envelope to the office, please place it in the bin labeled "Mountain Research Project."

Thank you for your help.

Yours sincerely,

Robert Rinkoff, Ph.D.

Professor, School of Early Childhood Education

Ryerson University 


\section{Appendix B \\ Survey Questions for Children \\ 'Nature' Section Adapted from: Rinkoff and Gaston (2008)}

School:

Grade:

Room:

\section{Survey for Children}

Instructions for Parents or Guardians:

Dear Parents or Guardians,

Please take a few minutes to help your child answer the following questions about mountains and nature as necessary. If your child needs help reading the instructions or the questions or does not understand a word or a question, please assist them. If your child needs help writing an answer, it is okay for you to write down what they tell you. It is also okay if your child fills out the survey over a few sessions, rather than all at once.

Please let your child answer each question in their own way. Please do not coach them or remind them about past experiences. It is possible that your child's answers may not agree with the answers you provide on the Survey for Parents. This is okay. We would like to learn how young children think about and remember these things.

\section{Instructions for Children:}

\section{Dear Children,}

Please take a few minutes to answer the following questions about mountains and nature. If you need any help with a word or question, please ask a parent (or an adult looking after you). The answers should come from you - we are interested in what you think and remember - but if you have trouble writing any answers, you can ask a parent (or another adult) to write out what you tell them.

Remember that this is not a test. We just want to know what you think.

Thank you very much for your help. We hope you enjoy the questions. 
Questions about Nature

24. Please take a moment to think about nature. Please write down words about nature that come to mind.

25. How much a part of nature do you feel you are? Please check one answer
a. I don't feel like a part of nature at all.
b. I feel like a part of nature a little bit.
c. I feel like I am very much a part of nature.
d. I feel that I am completely a part of nature.

26. How much part of nature do you feel the place where you live is? Please check one answer.
a. I feel that where I live is not a part of nature at all.
b. I feel that where I live is a part of nature a little bit.
c. I feel that where I live is very much a part of nature.
d. I feel that where I live is completely a part of nature. 


\author{
Appendix C \\ Survey Questions for Parents \\ 'Nature' Section Adapted from: Rinkoff and Gaston (2008)
}

School:

Child's Grade:

Room:

Instructions:

\title{
Survey for Parents
}

Please take a few minutes to answer the following questions about your thoughts, feelings, and experiences with mountains, nature, and wilderness. When answering the questions, please keep in mind that this survey will be filled out by parents/guardians living in different places, both in or near mountains and in a city.

If possible, please go through this Parent Survey before doing the Survey for Children. Also, please look over the Survey for Children in case your child has any questions. Please do this before giving it to your child to complete.

Thank you very much for your time and consideration,

Robert Rinkoff, Ph.D.

School of Early Childhood Education

Ryerson University

Toronto, Ontario, Canada
Gabriel Epstein

Elementary School Teacher (retired)

Toronto District School Board

Toronto, Ontario, Canada

\section{Questions about Nature}

24. Please take a moment to think about nature. Please write down words about nature that come to mind.

25. How much a part of nature do you feel you are? Please check one answer
a. I don't feel like a part of nature at all.
b. I feel like a part of nature a little bit.
c. I feel like I am very much a part of nature.
d. I feel that I am completely a part of nature.

27. How much part of nature do you feel the place where you live is? Please check one answer.
a. I feel that where I live is not a part of nature at all.
b. I feel that where I live is a part of nature a little bit.
c. I feel that where I live is very much a part of nature.
d. I feel that where I live is completely a part of nature. 


\section{Appendix D}

Diagram of Triangulation Method

Adapted from: Creswell (2005)

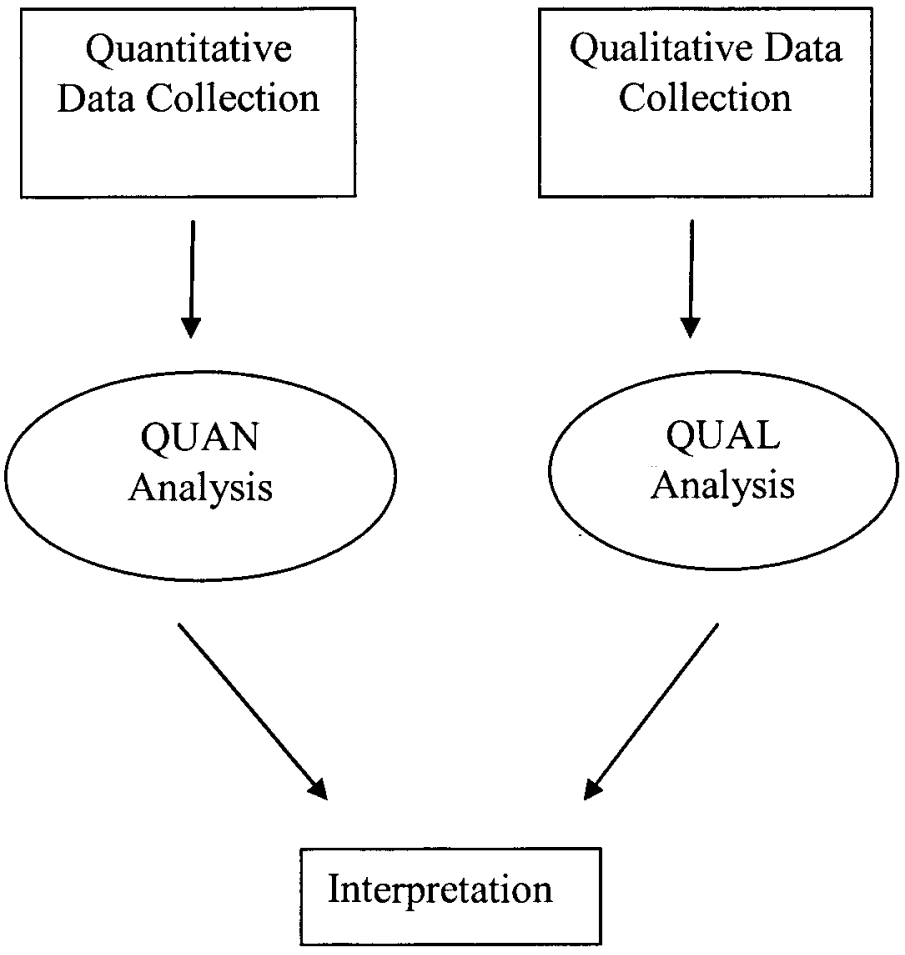




\section{Appendix E}

Definitions of Word Categories

Adapted from: Rinkoff and Gaston (2008)

\begin{tabular}{|l|l|}
\hline \multicolumn{1}{|c|}{ Name of Category } & \\
\hline Emotion: & Words that evoked emotions such as happiness, peace, and beautiful. \\
\hline Animal: & Words that involved animal names such as duck, birds and animals. \\
\hline Plant: & $\begin{array}{l}\text { Words such as flower, tree, and simply plants. } \\
\text { as, including lakes, air } \text { and } \text { earth. }\end{array}$ \\
\hline Element: & $\begin{array}{l}\text { Words that an individual used to describe nature, such as green, big } \\
\text { and tall. }\end{array}$ \\
\hline Descriptive: & $\begin{array}{l}\text { Words that described an action that a participant associated with } \\
\text { nature, including skiing, hiking and camping. }\end{array}$ \\
\hline Total: & $\begin{array}{l}\text { All of the words were counted and recorded in this category. The total } \\
\text { number of words included prepositions such as as, and } \text { or to that did }\end{array}$ \\
\hline Action: & nould be described \\
\hline
\end{tabular}


Appendix F

Breakdown of Participants

\begin{tabular}{|l|l|}
\hline \multicolumn{2}{|c|}{ Children } \\
\hline Total & 103 \\
\hline Urban & 40 \\
\hline Mountainous & 63 \\
\hline
\end{tabular}

\begin{tabular}{|l|l|}
\hline \multicolumn{2}{|c|}{ Parents } \\
\hline Total & 89 \\
\hline Urban & 36 \\
\hline Mountainous & 53 \\
\hline
\end{tabular}

Total Participants: 192 


\author{
Appendix G \\ Assent Agreement for Children \\ Adapted from: Rinkoff and Gaston (2008)
}

\author{
Ryerson University \\ Assent Agreement For Children
}

"Children and the Mountain Environment: Exploration and Education"

\title{
Instructions for Parent or Guardian:
}

Dear Parent or Guardian, please read this to your child before he/she begins the Survey. If your child is old enough to read it by himself/herself, that is alright, too. Please answer any questions your child has regarding their participation in this study as best you can.

\section{What is this about?}

You are being asked to take part in a research study dealing with Children and Mountains. Whether or not you participate is up to you. You do not have to do anything you do not want to do.

\section{Who is Doing the Study?}

The study is being done by Dr. Robert Rinkoff, a Professor at Ryerson University in Toronto, Canada, and Mr. Gabriel Epstein, a retired Toronto elementary school teacher.

\section{What is the Purpose of the Study?}

The purpose of this study is to see if where you live and how old you are affects what you know about mountains, wilderness, and nature. To do this, we are asking you to fill out a Survey and, possibly, to come to a later Follow-up Discussion Group at school.

We are also asking your parents (or the adults looking after you) and your teachers questions about these topics.

When we have collected the information, we hope to help teachers teach about mountains and mountain wilderness in a better way. We also hope to learn more about what people know about mountains and how they feel about them. We will use the information to write some articles and develop teaching materials in elementary schools like yours.

We are asking children from four different elementary schools in three countries, along with their parents (or the adults looking after them) and their teachers, to participate in this study. In total we hope to have about 300 children, their parents (or the adults looking after them), and 1215 teachers involved in the project.

\section{What's Involved?}

If you are willing to be a part of this study, we ask you to fill out the Survey for Children. The Survey asks questions about mountains, wilderness, and nature. You can fill it out anywhere you like. It should take you about $20-25$ minutes. You can ask your parents (or one of the adults 
looking after you) for help in reading a question or for help writing down your answer if you want to. You do not have to finish the Survey all at once.

\section{Could Anything Bad Happen?}

We don't see anything bad that could happen when you take part in this study. The questions are ones we hope you will find interesting. We won't be asking for your name, so the answers you write will be private. No one will know what your answers are. Even the name of your school will not be mentioned.

You do not have to answer any questions you don't want to. If you change your mind and don't want to hand in your Survey at all, that's also okay.

\section{What if I have some Questions about the Study?}

If you have any questions about the study, please ask your parent (or an adult looking after you). If they can't answer the questions, they can contact Dr. Rinkoff.

\section{What Next?}

If you would like to be a part of this study, please tell your parent (or an adult looking after you) and they can give you the Survey for Children to fill out. Remember that you can take your time and can always ask for help. If you return the Survey, it will mean that you think it is okay for us to add your answers to those of the other children in our study.

\section{Is there a Second Part of the Study I could ioin?}

Yes, there will be some Follow-up Discussion Groups at your school. Each group will have six to ten children and take between 20 and 35 minutes. We will give you a chance to talk about mountains, wilderness, and nature. The groups will not meet during your regular class time.

In the Follow-up Discussion Group, the person leading the group will not include your name in anything he says or writes. He will also ask all the children in the group not to tell anybody else about who said things during the discussion, but he can't be sure that the other children will do this.

If you want to participate in a Follow-up Discussion Group, we will ask for permission to taperecord the discussion so we can better remember what is said. No names will be included in any notes we make from the tape recording. If you do not want us to tape-record the discussion, we won't do that, but will just write down what people say.

If you are interested in being part of a Follow-up Discussion Group, please let you parent (or an adult looking after you) know. If you want to, you can decide this after you see the Survey. 


\section{Appendix H}

Assent Agreement for Parents

Adapted from: Rinkoff and Gaston (2008)

\section{Ryerson University \\ Consent Agreement}

For Parents or Guardians

\section{"Children and the Mountain Environment: Exploration and Education"}

You are being asked to participate in a research study. Before you give your consent to be a volunteer, it is important that you read the following information and ask as many questions as necessary to be sure you understand what you will be asked to do.

\section{Investigators:}

Robert Rinkoff, Ph.D.

Professor

School of Early Childhood Education

University

Toronto, Ontario, Canada
Gabriel Epstein

Elementary School Teacher (retired)

Toronto District School Board Ryerson

Toronto, Ontario, Canada

\section{Purpose of the Study:}

The purpose of this study is to investigate how children's and parents' knowledge of and relationship to mountains, wilderness, and nature vary according to where they live and how old the children are. A second purpose is to compare how mountains, wilderness, and nature are addressed in the elementary school curriculum in different locations.

As a result of the information collected, we hope to (1) develop teaching materials that will enhance elementary school curricula as they relate to mountains and mountain wilderness and (2) further our understanding of children's and parents' knowledge of and relationships to mountains. The findings will be used for publication and curricular development.

Children from selected elementary school grades, their parents/guardians, and their teachers from four schools in three countries are being asked to participate in this study. In total, it is hoped that about 300 children, their parents/guardians, and 12-15 teachers will be involved.

\section{Description of the Study:}

If you are willing to participate in this study, we ask you to fill out the Survey for Parents and assist your child as necessary in filling out the Survey for Children. You may do this in any place you find appropriate. It is anticipated that it will take parents/guardians about $10-15$ minutes to fill out their survey and children about $20-25$ minutes. These surveys ask about your knowledge of, thoughts about, and experience with mountains, wilderness, and nature as well as those of your child. 
As a follow-up to the Survey for Children, we would like to meet with groups of six to ten children at school to ask them some discussion questions about mountains, wilderness, and nature. These questions would allow the children to talk at greater length than a survey allows. Some sample discussion questions are:

- Please describe what it is like to hike up a mountain (if you have done this) or what it might be like (if you have never hiked up one before). What does it feel like on the way up? What does it feel like to be on top? What does it feel like on the way down?

- How do you feel when you think about mountains?

- How do you feel when you think about wilderness in mountains?

These Follow-up Discussion Groups would take place at a school location and time determined by the school principal and would take between 20 and 35 minutes, depending on the age of the children. No class time would be used.

Since we will not be asking you to put your names on the Surveys, we ask that if you and your child are willing to have your child participate in a Follow-up Discussion Group, you indicate this at the end of this Consent Agreement.

What is Experimental in this Study: None of the surveys or discussion groups used in this study are experimental in nature. The only experimental aspect of this study is the gathering of information for the purpose of analysis.

Risks or Discomforts: There is no foreseeable risk of harm to the people participating in this study. All information collected will be anonymous. If you or your child do not want to answer any questions, you may choose not to do so. Questions are non-threatening; however, if any question makes you or your child feel uncomfortable, it can be left blank. You may also withdraw from the study at any time without penalty.

Benefits of the Study: As mentioned above under Purpose of the Study, anticipated benefits of this study are the creation of teaching materials that will enhance elementary school curricula as they relate to mountains and mountain wilderness - both for your child's school and in general and the furthering of our understanding of children's and parents' knowledge of and relationships to mountains. We cannot guarantee, however, that you or any other participant will personally receive any benefits from participating in this study.

Confidentiality: Confidentiality of the information collected will be maintained in the following ways: the schools participating in the study will not be named; participants will not be asked for their names and survey responses will be anonymous; findings will mostly be presented in aggregate (summary) form, but some individual quotes from responses may be used anonymously; and children who are willing to participate in a follow-up discussion group will be informed that while confidentiality of what is said can be maintained by the researcher, its maintenance cannot be guaranteed by the other members of the discussion group.

If you and your child agree for your child to participate in a follow-up discussion group, we will ask for permission to audio tape-record the discussion so it can be transcribed at a later date. No 
names will be used to identify discussion group participants and any names mentioned in the follow-up discussion will be edited out. If you or your child do not want us to tape-record the discussion, we won't do that, but will just write down what people say.

The data will be stored in a locked cabinet in a locked office. Only the researchers will have access to it.

Incentives to Participate: No incentives will be given to participants.

Costs and/or Compensation for Participation: There will be no costs for people to participate in this study, nor will any compensation be given for participation.

Voluntary Nature of Participation: Participation in this study is voluntary. Your choice of whether or not to participate will not influence your future relations with Ryerson University. If you decide to participate, you are free to withdraw your consent and to stop your participation at any time without penalty or loss of benefits to which you are allowed.

At any point in the study, you may refuse to answer any particular question or stop participation altogether.

Questions about the Study: If you have any questions about the research now or later, please contact:

\section{Robert Rinkoff}

School of Early Childhood Education

Ryerson University

or

through your

350 Victoria Street

School Office

Toronto, Ontario, Canada M4R 1H8

Telephone: 416-979-5000 extension 6332

E-Mail: rrinkoff@ryerson.ca

Continued next page... 
If you have questions regarding your rights as a human subject and participant in this study, you may contact the Ryerson University Research Ethics Board for information:

Research Ethics Board, c/o Office of Research Services, Ryerson University, 350 Victoria Street, Toronto, ON, Canada M5B 2K3. Telephone: 416-979-5042.

\section{Agreement:}

Since your responses will be anonymous, we will not be asking you to sign this Consent Agreement. Instead, please note that if you return the Survey(s) we will take this to mean that you agree to be in the study and that you give us permission to use the information you provide in the research project.

It will also indicate that you have read the information in this agreement and have had a chance to ask any questions you have about the study. It also indicates that you have been told that you can change your mind and withdraw your consent to participate at any time.

You may keep this copy of the agreement.

(Please cut here and return with your survey to give permission for your child to participate in the Follow-up Discussion Group)

\section{Follow-up Discussion Group Permission}

If you and your child are willing for your child to participate in a Follow-up Discussion Group, please identify your child by first name and last initial only and sign just your initials below.

Child's First Name:

Child's Last Initial:

Parent's/Guardian's Initials:

If you are willing to have your child participate in a Follow-up Discussion Group, please check one of the following boxes. (We will also be asking each child for permission.)

$\square$ Yes, you have my permission to audio tape-record the discussion group.

No, you do not have my permission to audio tape-record the discussion group. 
Appendix I

T-Test Scores for Children

\section{Group Statistics}

\begin{tabular}{|ll|r|r|r|r|}
\hline & mntVScity & $\mathrm{N}$ & Mean & Std. Deviation & $\begin{array}{c}\text { Std. Error } \\
\text { Mean }\end{array}$ \\
\hline Emotion & Mountain & 15 & 2.00 & 1.309 & .338 \\
& City & 11 & 1.00 & .000 & .000 \\
Animals & Mountain & 41 & 1.76 & 1.655 & .258 \\
& City & 27 & 1.74 & 1.130 & .217 \\
Plants & Mountain & 39 & 2.08 & .929 & .149 \\
& City & 28 & 2.00 & .943 & .178 \\
Elements & Mountain & 16 & 1.44 & .727 & .182 \\
& City & 22 & 1.64 & .902 & .192 \\
Descriptive & Mountain & 18 & 1.33 & .594 & .140 \\
& City & 11 & 2.00 & 1.265 & .381 \\
Action & Mountain & 5 & 1.20 & .447 & .200 \\
& City & 5 & 1.20 & .447 & .200 \\
Total & Mountain & 63 & 6.16 & 5.332 & .672 \\
& City & 40 & 6.63 & 4.055 & .641 \\
\hline
\end{tabular}


Independent Samples Test

\begin{tabular}{|c|c|c|c|c|c|c|c|c|c|c|}
\hline & & \multicolumn{2}{|c|}{$\begin{array}{l}\text { Levene's Test for } \\
\text { Equality of Variances }\end{array}$} & \multicolumn{7}{|c|}{ t-test for Equality of Means } \\
\hline & & \multirow[b]{2}{*}{$F$} & \multirow[b]{2}{*}{ Sig. } & \multirow[b]{2}{*}{$t$} & \multirow[b]{2}{*}{$d f$} & \multirow[b]{2}{*}{ Sig. (2-tailed) } & \multirow{2}{*}{$\begin{array}{c}\text { Mean } \\
\text { Difference }\end{array}$} & \multirow{2}{*}{$\begin{array}{l}\text { Std. Error } \\
\text { Difference }\end{array}$} & \multicolumn{2}{|c|}{$\begin{array}{l}95 \% \text { Confidence } \\
\text { Interval of the } \\
\text { Difference }\end{array}$} \\
\hline & & & & & & & & & Lower & Upper \\
\hline Emotion & $\begin{array}{l}\text { Equal variances } \\
\text { assumed } \\
\text { Equal variances } \\
\text { not assumed }\end{array}$ & 24.994 & .000 & $\begin{array}{l}2.519 \\
2.958\end{array}$ & $\begin{array}{r}24 \\
14.000\end{array}$ & $\begin{array}{l}.019 \\
.010\end{array}$ & $\begin{array}{l}1.000 \\
1.000\end{array}$ & $\begin{array}{l}.397 \\
.338\end{array}$ & $\begin{array}{l}.181 \\
.275\end{array}$ & $\begin{array}{l}1.819 \\
1.725\end{array}$ \\
\hline Animals & $\begin{array}{l}\text { Equal variances } \\
\text { assumed }\end{array}$ & .526 & .471 & .042 & 66 & .967 & .015 & .364 & -.712 & .743 \\
\hline & $\begin{array}{l}\text { Equal variances } \\
\text { not assumed }\end{array}$ & & & .045 & 65.885 & .964 & .015 & .338 & -.659 & 690 \\
\hline Plants & $\begin{array}{l}\text { Equal variances } \\
\text { assumed }\end{array}$ & .225 & 637 & .332 & 65 & .741 & .077 & .231 & -.385 & .539 \\
\hline & $\begin{array}{l}\text { Equal variances } \\
\text { not assumed }\end{array}$ & & & .331 & 57.790 & .741 & .077 & .232 & -.388 & .542 \\
\hline Elements & $\begin{array}{l}\text { Equal variances } \\
\text { assumed } \\
\text { Equal variances } \\
\text { not assumed }\end{array}$ & 1.112 & 299 & $\begin{array}{l}-.726 \\
-.751\end{array}$ & $\begin{array}{r}36 \\
35.552\end{array}$ & $\begin{array}{l}.473 \\
.457\end{array}$ & $\begin{array}{l}-.199 \\
-.199\end{array}$ & $\begin{array}{l}.274 \\
.265\end{array}$ & $\begin{array}{l}-.754 \\
-.736\end{array}$ & $\begin{array}{l}.357 \\
.338\end{array}$ \\
\hline Descriptive & $\begin{array}{l}\text { Equal variances } \\
\text { assumed } \\
\text { Equal variances } \\
\text { not assumed }\end{array}$ & 3.858 & .060 & $\begin{array}{l}-1.930 \\
-1.641\end{array}$ & $\begin{array}{r}27 \\
12.742\end{array}$ & $\begin{array}{l}.064 \\
.125\end{array}$ & $\begin{array}{l}-.667 \\
-.667\end{array}$ & $\begin{array}{l}.345 \\
.406\end{array}$ & $\begin{array}{l}-1.375 \\
-1.546\end{array}$ & $\begin{array}{l}.042 \\
.213\end{array}$ \\
\hline Action & $\begin{array}{l}\text { Equal variances } \\
\text { assumed } \\
\text { Equal variances } \\
\text { not assumed }\end{array}$ & . & 1.000 & $\begin{array}{l}.000 \\
.000\end{array}$ & $\begin{array}{r}\text { B } \\
8.000\end{array}$ & $\begin{array}{l}1.000 \\
1.000\end{array}$ & $\begin{array}{l}.000 \\
.000\end{array}$ & $\begin{array}{l}.283 \\
.283\end{array}$ & $\begin{array}{l}-.652 \\
-.652\end{array}$ & $\begin{array}{l}.652 \\
.652\end{array}$ \\
\hline Total & $\begin{array}{l}\text { Equal variances } \\
\text { assumed }\end{array}$ & .349 & .556 & -.473 & 101 & .637 & -.466 & .986 & -2.423 & 1.490 \\
\hline & $\begin{array}{l}\text { Equal variances } \\
\text { not assumed }\end{array}$ & & & -.502 & 97.617 & .617 & -.466 & .929 & -2.309 & 1.377 \\
\hline
\end{tabular}




\section{Appendix $\mathbf{J}$}

T-Test Scores for Parents

\begin{tabular}{|ll|r|r|r|r|}
\hline & MtnCity & $\mathrm{N}$ & Mean & Std. Deviation & $\begin{array}{c}\text { Std. Error } \\
\text { Mean }\end{array}$ \\
\hline Emotion & Mountain & 28 & 2.00 & 1.122 & .212 \\
& City & 19 & 1.84 & 1.167 & .268 \\
Animals & Mountain & 19 & 1.42 & .692 & .159 \\
& City & 17 & 1.29 & .686 & .166 \\
Plants & Mountain & 20 & 1.90 & .912 & .204 \\
& City & 17 & 2.00 & .866 & .210 \\
Elements & Mountain & 23 & 1.70 & 1.146 & .239 \\
& City & 14 & 1.93 & 1.639 & .438 \\
Descriptive & Mountain & 33 & 1.82 & .882 & .154 \\
& City & 25 & 2.12 & 1.563 & .313 \\
Action & Mountain & 2 & 3.00 & 2.828 & 2.000 \\
& City & 1 & 3.00 & &. \\
Total & Mountain & 52 & 7.75 & 13.599 & 1.886 \\
& City & 36 & 5.97 & 4.706 & .784 \\
\hline
\end{tabular}




\begin{tabular}{|c|c|c|c|c|c|c|c|c|c|c|}
\hline \multicolumn{11}{|c|}{ Independent Samples Test } \\
\hline & & \multicolumn{2}{|c|}{$\begin{array}{l}\text { Levene's Test for } \\
\text { Equality of Variances }\end{array}$} & \multicolumn{7}{|c|}{ t-test for Equality of Means } \\
\hline & & \multirow[b]{2}{*}{$\mathrm{F}$} & \multirow[b]{2}{*}{ Sig. } & \multirow[b]{2}{*}{$t$} & \multirow[b]{2}{*}{$d f$} & \multirow[b]{2}{*}{ Sig. (2-tailed) } & \multirow{2}{*}{$\begin{array}{c}\text { Mean } \\
\text { Difference }\end{array}$} & \multirow{2}{*}{$\begin{array}{l}\text { Std. Error } \\
\text { Difference }\end{array}$} & \multicolumn{2}{|c|}{$\begin{array}{l}95 \% \text { Confidence } \\
\text { Interval of the } \\
\text { Difference }\end{array}$} \\
\hline & & & & & & & & & Lower & Upper \\
\hline Emotion & $\begin{array}{l}\text { Equal wariances } \\
\text { assumed }\end{array}$ & .788 & .379 & .466 & 45 & .644 & $.15 B$ & .339 & -.525 & .841 \\
\hline & $\begin{array}{l}\text { Equal variances } \\
\text { not assumed }\end{array}$ & & & .462 & 37.756 & .647 & .158 & .342 & -.534 & .850 \\
\hline Animals & $\begin{array}{l}\text { Equal yariances } \\
\text { assumed }\end{array}$ & .438 & .513 & .551 & 34 & .585 & .127 & .230 & -.341 & .595 \\
\hline & $\begin{array}{l}\text { Equal variances } \\
\text { not assumed }\end{array}$ & & & .552 & 33.628 & .585 & .127 & .230 & -.341 & .595 \\
\hline Plants & $\begin{array}{l}\text { Equal variances } \\
\text { assumed }\end{array}$ & .040 & .842 & -.340 & 35 & .736 & -.100 & .294 & -.697 & .497 \\
\hline & $\begin{array}{l}\text { Equal variances } \\
\text { not assumed }\end{array}$ & & & -.342 & 34.537 & .735 & -.100 & .293 & -.695 & .495 \\
\hline Elements & $\begin{array}{l}\text { Equal wariances } \\
\text { assumed }\end{array}$ & .681 & .415 & -.509 & 35 & .614 & -.233 & .458 & -1.162 & .696 \\
\hline & $\begin{array}{l}\text { Equal variances } \\
\text { not assumed }\end{array}$ & & & -.467 & 20.793 & .645 & -.233 & .499 & -1.271 & .805 \\
\hline Descriptive & $\begin{array}{l}\text { Equal variances } \\
\text { assumed }\end{array}$ & 4.569 & .037 & -.932 & 56 & .355 & -.302 & .324 & -.951 & .347 \\
\hline & $\begin{array}{l}\text { Equal variances } \\
\text { not assumed }\end{array}$ & & & -.867 & 35.435 & .392 & -.302 & .348 & -1.009 & .405 \\
\hline Action & $\begin{array}{l}\text { Equal yariances } \\
\text { assumed }\end{array}$ & & & .000 & 1 & 1.000 & .000 & 3.464 & -44.016 & 44.016 \\
\hline & $\begin{array}{l}\text { Equal variances } \\
\text { not assumed }\end{array}$ & & & & . & & .000 & & & \\
\hline Total & $\begin{array}{l}\text { Equal variances } \\
\text { assumed }\end{array}$ & 1.258 & .265 & .753 & 86 & .454 & 1.778 & 2.362 & -2.918 & 6.473 \\
\hline & $\begin{array}{l}\text { Equal variances } \\
\text { not assumed }\end{array}$ & & & .870 & 67.235 & .387 & 1.778 & 2.042 & -2.299 & 5.854 \\
\hline
\end{tabular}


Appendix K

Sample of Word Document Chart

\begin{tabular}{|l|l|l|}
\hline Name of Word & Participant Number & Total Number of Word Used \\
\hline & & \\
\hline & & \\
\hline & & \\
\hline & & \\
\hline & & \\
\hline
\end{tabular}




\section{Appendix $L$}

Consent Agreement for Principals

Adapted from: Rinkoff and Gaston (2008)

\section{Ryerson University \\ Consent Agreement \\ For Principals}

"Children and the Mountain Environment: Exploration and Education"

You are being asked to give permission for your school to participate in a research study. Before you give your consent, it is important that you read the following information and ask as many questions as necessary to be sure you understand what will be involved.

\section{Investigators:}

Robert Rinkoff, Ph.D.

Professor

School of Early Childhood Education

University

Toronto, Ontario, Canada

\author{
Gabriel Epstein \\ Elementary School Teacher (retired) \\ Toronto District School Board Ryerson \\ Toronto, Ontario, Canada
}

Purpose of the Study: The purpose of this study is to investigate how children's and parents' knowledge of and relationship to mountains, wilderness, and nature vary according to where they live and how old the children are. A second purpose is to compare how mountains, wilderness, and nature are addressed in the elementary school curriculum in different locations.

As a result of the information collected, we hope to (1) develop teaching materials that will enhance elementary school curricula as they relate to mountains and mountain wilderness and (2) further our understanding of children's and parents' knowledge of and relationships to mountains. The findings will be used for publication and curricular development.

Children from selected elementary school grades, their parents/guardians, and their teachers from four schools in three countries are being asked to participate in this study. In total, it is hoped that about 300 children, their parents/guardians, and 12-15 teachers will be involved. (We have chosen grades 1,3 , and 5 for this study, unless you suggest otherwise.)

Description of the Study:If you are willing to allow your school to participate in this study, we will ask children in the selected grades and their parents/guardians to fill out survey questionnaires dealing with mountains, mountain wilderness, and nature. We will also invite children to participate in a follow-up discussion group. As well, we will ask the children's teachers some questions dealing with (1) curriculum and teaching as they relate to mountains, mountain wilderness, and nature; (2) their thoughts about mountains, mountain wilderness, and nature; and (3) very general demographic information regarding the children they teach. Copies of all documents will be provided to you. 
The questionnaires are expected to take $20-25$ minutes for the children and $10-15$ minutes for their parents/guardians. The children's follow-up discussion groups will include six to ten children each and last between 20 and 35 minutes, depending on the age of the children. The discussions with the teachers are expected to take about 30 minutes and can be conducted either individually or in small groups.

No class time will be used. Children will be asked to fill out their questionnaires at home. Follow-up discussion groups will take place outside of class time, as will any meetings with teachers.

I would also ask that your office be willing to act as a liaison by providing me with any messages from study participants who wish to contact me with questions they may have.

No data for the research project will be collected until the project has received approval from the Ryerson University Research Ethics Board. A copy of the letter of approval will be provided to each school.

What is Experimental in this Study: None of the surveys or discussion groups used in this study are experimental in nature. The only experimental aspect of this study is the gathering of information for the purpose of analysis.

Risks or Discomforts: There is no foreseeable risk of harm to the people participating in this study. The schools will not be named and all information collected will be anonymous. If participants do not want to answer any questions they may choose not to do so. Questions are non-threatening; however, if any question makes a person feel uncomfortable, it can be omitted. Participants may also withdraw from the study at any time without penalty.

Benefits of the Study: As mentioned above under Purpose of the Study, anticipated benefits of this study are the creation of teaching materials that will enhance elementary school curricula as they relate to mountains and mountain wilderness - both for your school and in general - and the furthering of our understanding of children's and parents' knowledge of and relationships to mountains. Results and curricular suggestions will be shared first with participating schools. We cannot guarantee, however, that you or any other participants will personally receive any benefits from participating in this study.

Confidentiality: Confidentiality of the information collected will be maintained in the following ways: the schools participating in the study will not be named; participants will not be identified by name and all responses will be anonymous; findings will mostly be presented in aggregate (summary) form, but some individual quotes from responses may be used anonymously. People who participate in a discussion group will be made aware that while confidentiality of what is said can be maintained by the researcher, its maintenance cannot be guaranteed by the other members of the discussion group.

The data will be stored in a locked cabinet in a locked office. Only the researchers will have access to it. 
Incentives to Participate: No incentives will be given to participants.

Costs and/or Compensation for Participation: There will be no costs for people to participate in this study, nor will any compensation be given for participation.

Voluntary Nature of Participation: Participation in this study is voluntary. Your choice of whether or not to allow your school to participate will not influence future relations with Ryerson University. If you decide to allow participation, you are free to withdraw your consent and to stop your participation at any time without penalty or loss of benefits to which you are allowed.

Questions about the Study: If you have any questions about the research now or later, please contact:

Robert Rinkoff

School of Early Childhood Education

Ryerson University

350 Victoria Street

Toronto, Ontario, Canada M4R 1H8

Telephone: 416-979-5000 extension 6332

E-Mail: rrinkoff@ryerson.ca

If you have questions regarding your school's rights or those of the participants in this study, you may contact the Ryerson University Research Ethics Board for information:

Research Ethics Board, c/o Office of Research Services, Ryerson University, 350 Victoria Street, Toronto, ON, Canada M5B 2K3. Telephone: 416-979-5042.

Agreement: Your signature below indicates that you have read the information in this agreement and have had a chance to ask any questions you have about the study. Your signature also indicates that you agree to allow your school to be in the study and have been told that you can change your mind and withdraw your consent to participate at any time. You have been given a copy of this agreement.

You have been told that by signing this consent agreement you are not giving up any of your legal rights.

Name of Principal (please print)

Signature of Principal

Signature of Investigator
Name of School

Date

Date 


\section{Resources}

\section{Website Links}

Bachler, K. (2002). Nature games for kids to play: Games your child or children can play outdoors with nature. Retrieved September 3, 2008, from http://www.essortment.com/all/naturegames_rbqb.htm.

Cole, K. (2003). Nature activities for kids. Retrieved September 3, 2008, from http://www.biglearning.org/treasureoutdoors.htm.

CorusTM Entertainment Inc. (2008). TreeHouse TV: Outdoor nature activities for children. Retrieved September 3, 2008, from http://treehousetv.com/blogs/read_outdoor_fun/archive/2007/08/03/outdoor-natureactivities-for-preschoolers.aspx.

Family Education Network. (2008). Outdoor activities for children aged 6 to 10 . Retrieved September 3, 2008, from http://fun.familyeducation.com/play/outdooractivities/33394.html.

Fitzpatrick, D.L. (2008). The Importance of Outdoor Play for Kids: Nature Activities Important for Children's Growth, Development. Retrieved September 4, 2008, from http://stayathomeparents.suite101.com/article.cfm/the_importance_of_outdoor_play_for_ki ds.

Gayle's Preschool Rainbow (2008). Outdoor play activity theme. Retrieved September 4, 2008, from http://www.preschoolrainbow.org/preschool-outdoor.htm.

Green Living Enterprises (2008). Outdoor enviro-activities for kids. Retrieved September 3, 2008, from http:/www.greenlivingonline.com/Family/outdoor-enviro-activities-for-kids/. 
Glorious Butterfly. (2008). Outdoor Nature Activities for Kids with Butterflies. Retrieved

September 4, 2008, from http://www.glorious-butterfly.com/outdoor-nature-activities-forkids.html.

Outdoor Nature Child. (2006). Nature activities and games. Retrieved September 3, 2008, from http://www.outdoor-nature-child.com/nature-activities.html.

The New York Times Company (2008). Top 8 Outdoor Party Games for Kids. Retrieved September 4, 2008, from http://childparenting.about.com/od/kidsparties/tp/outdoorpartygam.htm

\section{Books}

Cornell, J. (2002). Sharing nature with children: The classic parents' \& teachers' nature awareness guidebook. California: Dawn.

Danks, F. (2002). Nature's playground: Activities, crafts, and games to encourage children to get outdoors. Chicago: Chicago Review Press.

Louv, R. (2008). Last child in the woods: Saving our children from nature-deficit disorder. New York: Workman.

Lingelbach, J. \& Purcell, L. (2000). Hands-on nature: Information and activities for exploring the environment with children. Vermont: Vermont Institute of Natural Sciences.

Petrash, C. (1992). Earthways: Simple environmental activities for young children. Toronto: Monarch Books of Canada.

Ward, J. (2008). I Love Dirt!: 52 Activities to help you and your kids discover the wonders of nature. San Diego: Shambhala. 


\section{References}

Alp, E., Ertepinar, H., Tekkaya, C., \& Yilmaz, A.(2008). A survey on Turkish elementary school students' environmental friendly behaviours and associated variables. Environment Education Research, (14), 129-143.

Barraza, L. (1999). Children's drawings about the environment. Environmental Education Research, 5(1), 49-66.

Bonnett, M., \& Williams, J. (1998). Environmental education and primary children's attitudes towards nature and the environment. Cambridge Journal of Education, 28(2), 159.

Cambridge Dictionary (2008). Cambridge online dictionary, retrieved March 19, 2008, from http://dictionary.cambridge.org.

Cohen, L., Manion, L, \& Morrison, K. (2003). Research methods in education (5th ed). New York: Routledge Falmer.

Creswell, J. W. (2005). Educational research. Planning, conducting and evaluating quantitative and qualitative research. Upper Saddle River, N. J.: Pearson Merrill Prentice Hall.

Del Balso, M. \& Lewis, A. (2001). First steps: A guide to social research. Toronto: Thomas Nelson Learning.

Devine-Wright, P., Devine-Wright, H., \& Fleming, P. (2004). Situational influences upon children's beliefs about global warming and energy. Environment Education Research, (10), 493 - 506.

Haluza-Delay, R. (2001). Nothing here to care about: Participant constructions of nature following a 12-day wilderness program. The Journal of Environmental Education, 32(4), 43-48. 
Hamilton, J.D., Klebanoff, A.M., \& Sharp,W.L. (1991). Bridging early childhood and nature education: Proceedings of the Roger Tory Peterson institute of natural history forum. Jamestown, NY: Roger Tory Peterson Institute of Natural History Inc.

Hogan, D., \& Greene,S. (Eds.) (2005). Researching children's experience: Approaches and Methods. London: Sage.

Hyun, E. (2005). How is young children's intellectual culture of perceiving nature different from adults'? Environment Education Research, (11), 199-214.

Johnson- Pynn, J.S., \& Johnson, L, R.(2005). Successes and challenges in East African conservation education. The Journal of Environmental Education, 36(2), 25-39.

Korhonen, K., \& Lappalainen, A.(2004). Examining the environmental awareness of children and adolescents in the Ranomafana region, Madagascar. Environmental Education Research, 10(2), 195-216.

Moore, R.C., \& Wong, H.H. (1997). Natural learning: The life of an environmental schoolyard. Creating environments for rediscovering nature's way of teaching. Berkeley: MIG Communications.

Rinkoff, R. \& Gaston, A. (2008). The child's proximity to mountains as a predictor of environmental intimacy: Implications for stewardship. Unpublished Paper Presented at the Ryerson University Faculty of Community Services Scholarly, Research, and Creative Poster Exhibition, March 26, 2008.

Taylor, A.F., Kuo, F.E., \& Sullivan, W.C.(2002) Views of nature and self-discipline: Evidence from inner city children. Journal of Environmental Psychology, 22, 49-63.

Van Petegem, P., \& Blieck, A.(2006). The environmental worldview of children: a cross-cultural perspective. Environmental Education Research, 5(12), 625-635. 
Wells, N.M., \& Evans, G.W.(2003). Nearby nature: A buffer of life stress among rural children. Environment and Behavior,35(3), 311-330.

Wells, N., \& Lekies, K.(2006). Nature and the life course: Pathways from childhood nature experiences to adult environmentalism. Children, Youth and Environments, 16(1), 1-24.

Pergams, O., \& Zaradic, P. (2006). Is love of nature in the US becoming love of electronic media? 16 -year downtrend in national park visits explained by watching movies, playing video games, internet use, and oil prices. Journal of Environmental Management, 80, 387393.

Zaradic, P., \&Pergams, O. (2007). Videophilia: Implications for childhood development and conservation. The Journal of Developmental Processes, 2(1), 103- 147.

Zeece, D., \& Wells, R.(2007). My place in the world: Literature for play-based environmental education. Early Childhood Education Journal,(35), 285- 291. 